OPEN ACCESS

Edited by:

Jieling Xiao

Birmingham City University,

United Kingdom

Reviewed by:

Dmitrijs Dmitrenko,

University of Sussex, United Kingdom George Ghinea,

Brunel University London,

United Kingdom

Emanuela Maggioni,

University College London,

United Kingdom

*Correspondence:

Charles Spence

charles.spence@psy.ox.ac.uk

Specialty section:

This article was submitted to

Environmental Psychology,

a section of the journal

Frontiers in Psychology

Received: 29 April 2021

Accepted: 11 June 2021

Published: 12 July 2021

Citation:

Spence C (2021) Scent in Motion: On the Multiple Uses of Ambient Scent in the Context of Passenger Transport.

Front. Psychol. 12:702517.

doi: 10.3389/fpsyg.2021.702517

\section{Scent in Motion: On the Multiple Uses of Ambient Scent in the Context of Passenger Transport}

\author{
Charles Spence* \\ Head of the Crossmodal Research Laboratory, University of Oxford, Oxford, United Kingdom
}

There is undoubtedly growing interest in the role of scent in the design of multisensory experiences. However, to date, the majority of the research has focused on its use in the (static) built environment. As highlighted by this narrative review, somewhat different challenges and opportunities arise just as soon as one starts to consider olfaction in the case of transportation-what might be called "scent in motion." For instance, levels of anxiety/stress while traveling are often higher (especially in the case of air travel), while, at the same time, the passenger's personal space is frequently compromised. Four key functional roles for scent in the context of passenger transportation are outlined. They include the masking of malodour, the introduction of branded signature scents, short-term olfactory marketing interventions, and the functional use of scent to enhance the experience of travel. In the latter case, one might consider the use of scent to help reduce the stress/anxiety amongst airplane passengers or to give the impression of cleanliness. Meanwhile, in the case of driving, scents have been suggested as an inoffensive means of alerting/relaxing the driver and may also help tackle the problem of motion sickness. The specific challenges associated with scent in motion are reviewed and a number of future opportunities highlighted.

Keywords: transport, malodour, scent, functional scents, signature scents, scent marketing

\section{INTRODUCTION}

Scent plays an important role in our experience of the built environment (see Spence, 2020c, for a recent review). This should come as little surprise when it is realized that the world's majority urban population spends an estimated $90-95 \%$ of their time indoors (Ott and Roberts, 1998; Klepeis et al., 2001; Wargocki, 2001; Velux YouGov Report, 2018) ${ }^{1}$. In this review, I will consider the role played by ambient scent in passenger transportation-what might be considered "scent in motion," though, as we will see later, sometimes it will be more a case of "stench in motion" (Robinson, 2016). To give some context, North Americans spend an average of an hour a day behind the wheel (https://www.volpe.dot.gov/news/how-much-time-do-americans-spend-behind-wheel), be it the daily commute or the school run (see also Chapin, 1974). This represents a not inconsiderable source of stress for many people, especially when their travel is, for whatever reason, impeded (Novaco et al., 1990). Indeed, commuting/travel is one of the few aspects of our daily lives that has not gotten any faster as the decades have gone by Colvile (2017). At present, average speeds in

\footnotetext{
${ }^{1}$ Currently, around $55 \%$ of the population live are thought to live in urban areas, up from $30 \%$ in 1950, see https://www.un. $\mathrm{org} /$ development/desa/en/news/population/2018-revision-of-world-urbanization-prospects.html.
} 
the world's growing number of megacities are around $15 \mathrm{~km} / \mathrm{h}$ (Nyirinkindi and Paris, 2020), and that figure is predicted to drop down to $3 \mathrm{~km} / \mathrm{h}$ by 2030 .

Regardless of the sector (be it healthcare, retail, etc.), increasing competition in the marketplace typically leads to a greater focus on the experience. In the case of passenger transportation, the shift in focus is from the final destination and the duration/cost of the trip to a greater emphasis on the experiential qualities of the journey itself (as probed by the all too frequent request for feedback along the lines of "How was the experience?"). The much anticipated arrival of space tourism further promises to elevate transportation to an entirely new level, at least for the lucky few who can afford to partake in this admittedly niche activity (see Henderson and Tsui, 2019). Indeed, transportation is an especially dynamic sector currently, with radical challenges to conventional business models an increasingly common occurrence--think here only of the disruption offered by the likes of Neutonomy, Uber, and Tesla (see Smart, 2017; Woodward et al., 2017; Spence, 2021a; though see also Diao et al., 2021; Liberatore, 2021, on the downside of rideshare apps, otherwise referred to as Transportation Network Companies (TNCs), such as Uber and Lyft). What is more, the introduction of flying taxis may be closer than many people think (The Local, 2019; Pasztor and Tangel, 2020; see also Murphy, 2021). All that before we get to Richard Branson's Hyperloop Propulsion Pods, with matching signature scent (see Giacobbe, 2021). Given the highly-dynamic and competitive nature of the transportation market, there is a growing opportunity to enhance/differentiate the multisensory travel experience for passengers via design that targets the sense of smell.

That said, when thinking about the multisensory experience of travel, it is important to consider how our experience, especially of public transport, typically involves not only the time spent on the move but often requires the passengers to transit through, and often wait in, stations (see Schivelbusch, 2014, on the early history of the railway station), airports (Wattanacharoensil, 2019), bus/tram stops, etc. These spaces are, properly considered, therefore a part of the experience of travel too (cf. Goetz, 2019), though equally also fit within any discussion of scent in the built environment. Indeed, given the importance of primacy/recent effects to human memory, they may actually play a disproportionately important role in the passengers' memory of their travel experiences (see Carbone and Haeckel, 1994; Berry et al., 2002; Carbone, 2004; LaTour and Carbone, 2014, on the notion of "Sticktion"). Hence, in the narrative review that follows, I will look at the role of scent in all stages of the journey and across a wide range of different forms of travel. As we will see in a moment, though, while many of the same issues and opportunities present themselves in the case of scent in the built environment (static) and in the case of dynamic scent (i.e., transport), there are also a number of salient differences. It should also be noted that, as has just been mentioned, the distinction between scent in motion and scent's use in the built (i.e., static) environment is by no means always clear-cut, with stations, airports, etc. fitting naturally into both categories.

\section{Air Pollution}

The topic of air pollution is also very relevant to the themes of this review inasmuch as many forms of transportation are associated with high levels of air pollution, some of which are detected consciously by those who are themselves traveling, or else by others who may be in the vicinity. Indeed, levels of air pollution in and around different forms of transportation (i.e., both for those who are traveling and those who find themselves nearby) tend to be much higher than is commonly the case when considering the olfactory atmosphere of the built environment. For instance, just take Oxford Street in London, often mentioned as one of the most polluted streets in the world in terms of traffic-related air pollution (cf. Popovich et al., 2019). The levels of nitrogen dioxide $\left(\mathrm{NO}_{2}\right)$ recorded on this world-famous shopping street are dangerously (not to mention illegally) high more than $80 \%$ of the time.

The deleterious effects on respiratory health of such transportrelated pollution are well-documented (WHO Technical Report, 2013; van Veldhoven et al., 2019). Increased levels of air pollution may result in increased road rage amongst drivers. Consistent with such a view, almost 50 years ago, researchers in California had already highlighted how the number of road traffic accidents in Los Angeles correlated with the level of air pollution (Ury et al., $1972)^{2}$. Relevant here, therefore, is recent research reported by Dmitrenko et al. (2020) showing how pleasant scents can be used to promote safer driving, better mood, and improved well-being in angry drivers.

The air that people breathe in (in particular, the particulate matter) when traveling on underground transportation can be pretty toxic (cf. Gouveia and Maisonet, 2005; Paton, 2019; Radnedge, 2019), with a trip on the London Underground, the dirtiest in the world, exposing passengers to dangerously high levels of particulate matter. The levels of toxic airborne pollutants in the atmosphere in the London Underground, are currently almost 20 times higher than recommended by the World Health Organization (WHO). Given such shocking figures, one might think that adding a pleasant scent is probably the last thing that commuters should be worrying about. As another example of the olfactory pollution that was once associated with travel, one need only think back to the days when a flimsy cloth curtain was all that separated the smoking section at the back of the airplane from the rest of the non-smoking passengers. While a separate non-smoking section has been mandated in planes in the US since 1973, smoking was only banned completely on flights to/from or within the US in 2000, while the ban only came in much later in China; c. 2016; (Pallini, 2020). Given the well-established dangers of passive smoking, this would also have to constitute a pretty polluted olfactory environment (Crawford and Holcomb, 1991; Repace, 2004). Furthermore, one of the arguments put forward by those who are against airport expansion relates to the likely increase in air pollution experienced by those living in surrounding neighborhoods (e.g., see Anon, 2021b).

\footnotetext{
${ }^{2}$ Though, on reflection, perhaps this isn't all that surprising given that the more pollution there is, the more cars one might expect there to be on the roads, all else being equal.
} 
Fortunately, however, most of us typically spend much less time exposed to such pollutants (which may, or may not, be perceptible consciously), meaning that any deleterious effects on our health and well-being are, if not mitigated entirely, at least reduced significantly as compared to the volatile organic compounds (VOCs) that are typically found in poorlyventilated home or office environments where we spend so much more of our time (see Spence, 2002, 2021a; though see also Watson, 2021). Here, for instance, one might wonder whether there is an equivalent to the sick-building syndrome (SBS; Spence, 2002, 2020c; Love, 2018) that was sometimes reported half a century ago--something of the sort of sick transport syndrome (STS; a quick online search reveals the existence of Sick Yacht Syndrome, SYS; https://www.rgf.com/ article/sick-yacht-syndrome/)? ${ }^{3}$ There is, though, a separate question about exposure to air pollution amongst those who work in the transportation/travel industries (Repace, 2004; Bloomberg, 2017). Finally here, it is worth highlighting how the emergence of the Covid-19 pandemic, has bought into sharp focus the potentially infectious atmosphere while traveling on public transport (e.g., see Anon, 2021a; Bunyan, 2021)-and see Luke et al. (2020) for the crucial role that transportation played in facilitating the spread of the Spanish Flu a century earlier.

\section{Anxiety}

One of the other noticeable differences between scent in the built environment (see Spence, 2020a, Spence, 2020b) and scent in motion (e.g., in transportation) relates to the fact that for many of us, travel (especially air travel) is a major cause of anxiety. Historically, anxiety associated with transportation has often been triggered by the introduction of new, often much faster, forms of travel, such as, for example, the train (i.e., for those who were used to traveling by horse-drawn carriage or stagecoach; see Schivelbusch, 2014). Indeed, the palpable concerns of many early rail passengers (and a number of eminent doctors/medics), was eloquently brought out in Schivelbusch's 2014, The Railway Journey. Similarly, when the first public elevator was introduced in 1857 in the US (described in the initial patent as a "vertical railway"; Prisco, 2019), at the Manhattan Department store E.W. Haughtwhat \& Company in New York it was not a success, closing 3 years later (Bernard, 2014; Prisco, 2019). In this case, it may well have been the confined nature of the space (possibly triggering claustrophobia), not to mention the hidden nature of the underlying operations (mechanisms), that made the public nervous (e.g., Bernard, 2014; cf. Schivelbusch, 2014). The anxiety that this once novel form of transport gave rise to initially was eventually ameliorated by the introduction of mirrored surfaces (to show the passengers who else is in the lift with them, while also making the space look bigger) and the so-called busboy (whose presence continued long after it was strictly needed). Elevator music may also have been used to help calm those who felt anxious (see Friedrich, 1984; Lanza, 2004) ${ }^{4}$.

\footnotetext{
${ }^{3}$ That said, the incidence of SBS (Love, 2018) would appear to be in decline, perhaps due to improved ventilation.

${ }^{4}$ Relevant to the present review, while "elevator music" became an expression in its own right, I have heard no mention of elevator scent (though see Robinson, 2016; Valenti, 2018, for the Elevator Scent launched by Off White and Byredo).
}

Nowadays, though, the most anxiety-inducing form of public transport would appear to be air travel. To give some sense of the problem, $40 \%$ of the population in North America experiences some degree of anxiety associated with this form of travel. An estimated $6.5 \%$ of them suffer from a fear of flying known as aviophobia (Gould, 2017), while $2.5 \%$ have a clinical phobia. This means that they either avoid flying altogether or do so while enduring significant distress (Schaaff, 2019). This is, of course, somewhat ironic given the statistics showing that per mile traveled, one is significantly more likely to die when traveling by road than by air (Schaaff, 2019), as was much commented on following 9/11.

As we will see at several points in this review, driving represents a very particular form of transport inasmuch as there is a potentially important distinction between the driver and any passengers. While both share the same olfactory space/atmosphere, the majority of the multisensory interventions in this area have been targeted at the driver (e.g., alerting/relaxing them) rather than at their passengers ${ }^{5}$. Relevant here, it terms of anxiety, it has been suggested that many motorists appear to drive more dangerously following the introduction of the latest new car safety innovations. The suggestion is that this helps them to maintain a certain desirable level of perceived risk/anxiety, a phenomenon known as "risk compensation" (Peltzman, 1975; Wilde, 1982; Evans and Graham, 1991). Relevant to the theme of the present review, the research shows that ambient scents tend to exert a more positive effect over our mood and well-being when we are stressed/anxious than when we are calm (Warren and Warrenburg, 1993) ${ }^{6}$. Hence, it could be imagined that ambient scent would play a more important role in the context of transportation than in the context of the built environment.

\section{Personal Space}

Crowding is also often more likely to be a problem on public transport than is typically the case in the built environment (as highlighted by people's oft-discussed dislike of sitting in the middle seat on the train: McGeeham, 2005; Evans and Wener, 2007) ${ }^{7}$. Interpersonal space is much lower still when it comes to those passengers who are forced to travel in the confined space of mass transportation (be it Mass Transit or the London Tube) at rush hour that pretty much anywhere else (cf. Dipodjoyo, 2019). Is there any other situation, one might

\footnotetext{
One concern, though, about introducing scent in this case is the highly-confined nature of the space.

${ }^{5}$ The rise of the semi-autonomous and fully autonomous vehicles is, though, slowly starting to blur this particular distinction (Anon, 2016; Kurczewski, 2020). Relevant here, the potential use of scent to enhance an individual's trust in the context of autonomous driving represents a particularly intriguing direction for research (see Wintersberger et al., 2019).

${ }^{6}$ After a decade of research studying the impact of fragrance on mood and wellbeing for International Flavors \& Fragrances (IFF), one of the world's largest flavor houses, Warren and Warrenburg (1993, p. 9) arrived at the following conclusions: "1. Fragrance-evoked mood changes are small, but beneficial to our well-being. 2. Fragrance can be used to reduce the stress response in humans, but its physiological effects on a non-stressed subject are minimal and difficult to measure.".

${ }^{7}$ Meanwhile, keeping the middle seat on the airplane empty has been suggested to be an effective strategy to reduce Covid-19 infection rates while flying (Matthews, 2020).
} 


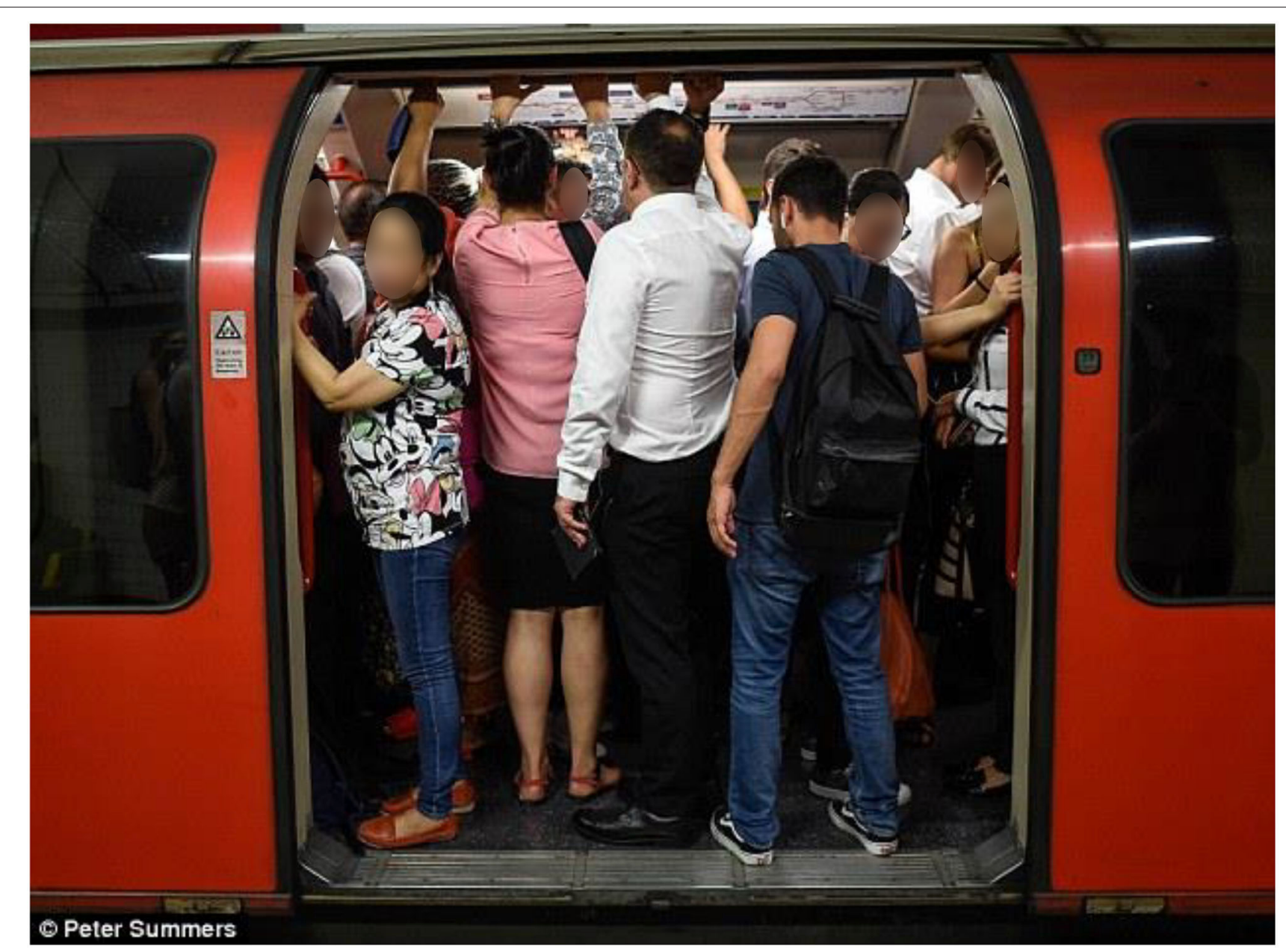

FIGURE 1 | Do we ever get closer to unknown strangers than on the underground? [Copyright P. Summers].

ask, where one's personal space is so radically compromised (see Figure 1)? Combined with the often high temperatures (Thompson, 2014) ${ }^{8}$ and lack of natural ventilation, this invasion of the passenger's personal space (Sommer, 1959, 1969; Horowitz et al., 1964; Felipe and Sommer, 1966; Dosey and Meisels, 1969; Kennedy et al., 2009) in the London Tube, but also on other forms of public transport, can soon lead to an awareness of other people's body odors that most of us would rather do without. The overpowering odors can be especially noticeable in the summertime when it can get very hot down there (according to one press report concerning the London Underground, in the summer it is sometimes above the legal temperature for transporting livestock; see Thompson, 2014). The reduced personal space brings the passenger much closer to the smell of unknown others than is typically the case elsewhere in our daily lives. What is more, this is typically found to be an unpleasant experience with those other unknown passengers of other races and/or social classes often suggested to have a

${ }^{8}$ Note that high temperatures have also been linked to increased anti-social behavior (Baron and Ransberger, 1978). distinctive, and frequently disliked, scent (e.g., Orwell, 1937; Largey and Watson, 1972; Classen, 1992; Manalansan, 2006; Bever, 2019) ${ }^{9}$.

One artist who has worked in this space is Angela Ellsworth. In a provocative piece of what I presume can only be called "olfactory performance art," Ellsworth wore a jersey cocktail dress soaked in her own urine to the opening reception for the Token City installation (a subway simulation) by artist Muriel Magenta at the Arizona State University Art Museum in 1997 (http://museumofwalking.net/ works/solo_actual1.html). According to Drobnick (2006), the idea behind the guerrilla art project (going by the name Actual Odor), was precisely to draw people's attention to the way in which malodour destroys any social boundaries that exist in a subway, as it permeates the space and transcends visual barriers or experiences.

${ }^{9}$ This, one of the themes brought out in Oscar-winning Korean movie, Parasite - a very dark comedy indeed (Lawless, 2020)!. 


\section{On the Rise of Olfactory Sensitivities}

The typically more confined space, and reduced interpersonal distance/space, involved in most forms of public transport differentiates it from our experience of the built environment (Spence, 2020a,b). As we will see below, the confined space may sometimes also increase people's sensitivity to any olfactory manipulation. At the same time, however, it is worth stressing how one of the challenges associated with the deliberate scenting of the built environment in recent decades has been the increasing complaints of those suffering from multiple chemical sensitivity (MCS) syndrome (Lacour et al., 2005). That said, the majority of cases of fragrance sensitivity that have been described in the literature would appear to have been triggered by personal fragrance rather than by ambient scent (Spence, 2002; Byatt, 2003; Fletcher, 2005; Caress and Steinemann, 2009; Steinemann, 2019). In turn, this may perhaps be related to the shift away from the overpoweringly-heavy personal fragrances that were such a distinctive feature of the 1980 's, at least in North America) ${ }^{10}$. According to the latest research, such enhanced responsivity to olfactory stimuli appears to reflect a response bias rather than enhanced sensitivity to particular odorants (Andersson et al., 2020). I am not aware of such complaints related to olfactory sensitivities having been tied to the ambient fragrancing of public transport.

\section{SCENT IN MOTION: THE MULTIPLE ROLES OF AMBIENT SCENT IN DIFFERENT FORMS OF TRANSPORT}

Traditional means of getting from a-to-b, such as walking, but also traveling on horseback, bicycle, or motorbike (Pirsig, 1974), or these days, on an e-scooter, have in common exposure to the elements. This typically includes the ambient scent of the built or natural environment through which a person is traveling ${ }^{11}$. What is lost, when this aspect of the experience is denied (e.g., due to anosmia), has been highlighted by various writers (e.g., Tafalla, 2013, 2014). Commentators have also drawn attention to the rich world of scent that pedestrians might encounter when moving through the city via the development of scent maps of cities such as the one made of Amsterdam (e.g., see Degen and Rose, 2012; though see also Tan, 2013; Henshaw, 2014; Poon, 2015; Leimbach, 2017; McLean, 2018). The contemporary experience of scent while passing through the city contrasts radically with the frequent historical complaint concerning the stench of human effluence that nearly always greeted the nostrils of those moving through urban areas in centuries gone by (e.g., Corbin, 1986;

\footnotetext{
${ }^{10}$ As an article in The New York Times in 1988 put it: "The American woman has acquired a taste for eaux de toilettes and colognes that are unusually strong and lasting" (Wells, 1988).

${ }^{11}$ Along these lines, one of the protagonists, Martha Coffin Wright in Dorothy Wickenden's The agitators, writes in a letter about the members of the pubic watching a wedding in 1860 in the United States that they were there: "to hear the music, and 'take a smell" (Wickenden, 2021, p. 162).
}

Potter, 1999; Jütte, 2005; el-Khoury, 2006; Bradley, 2015; see also Edensor, 2014; Misra, 2015) ${ }^{12}$.

While artists and designers have drawn attention to the olfactory interest/pleasure of a walk through the city, there has been far less research on the impact of such smells, and how they may interact, or be integrated, with other components of the multisensory environment (Ba and Kang, 2019a,b). Though it is worth noting that in these cases the observer is in motion while the scents themselves are static. More often than not, in the examples reviewed below, the scent is delivered from the vehicle or carriage that is itself moving. This observation, once again, hinting at the challenges associated with delivering a clear definition of what constitutes "scent in motion."

In the rest of this section, I would like to consider various of the major forms of transport ${ }^{13}$, and assess the differing role/opportunity that scent has played. However, rather than organizing this section on the basis of different modes of transport (be it bus, train, tram, or plane, etc.), it seemed more enlightening to organize the review around the four different principal purposes for which scent have seemingly been introduced into passenger transport. These are: masking malodour, olfactory marketing, signature scents, and functional scents.

\section{Scent in Motion: Masking Malodour/Pollution}

As has been noted already, levels of pollution are often much higher in or around transportation than in the built environment. While issues of noise pollution from various means of transport are a major cause for concern (e.g., Burne, 2014; Owen, 2019; Benfield et al., 2020), it is the olfactory, or atmospheric, component of pollution that will be the focus here. That said, it is important to note that many of the pollutants that are so bad for our health are not perceived consciously. One attempt to mask any unpleasant odors in the London Underground took place in 2001, when a pleasant scent by the name of "Madeleine" was introduced for a trial period into several stations. The fragrance had already been introduced successfully into the Paris Metro in 1998, not to mention in the Hong Kong Metro. It must therefore have seemed like a good idea to those in charge of Transport for London to do the same. A scent-encapsulated fragrance described as smelling like "a fresh, watery floral bouquet of rose and jasmine, combined with citrus top notes, tiny touches of fruit and herbs, giving way to woody accents and a hint of sweetness in the base" was deposited on the floors in St. James' Park, Euston, and Piccadilly stations to be released when the passengers walked over them.

The confined space on the underground, where people have no choice but to breathe in the air, makes the deliberate introduction of ambient scent a more sensitive and challenging topic than it might be elsewhere. Indeed, the commuters soon started to complain once they became aware of what was going on. In this case, part of the problem, may have been the fragrance

\footnotetext{
${ }^{12}$ Intriguingly, though, some Ancient Roman sources actually have the citydwellers complaining about the foul goaty/garlicky smell that greeted their nostrils on visiting the countryside (Morley, 2015, p. 117).

${ }^{13}$ Transport is defined as taking or carrying (people or goods) from one place to another by means of a vehicle, aircraft, or ship etc.
} 
itself, which was described by one commuter as a "cheap fragrance that smells slightly like industrial cleaner. It's a good idea as long as you use a fragrance that doesn't make the station smell like a toilet." (quoted in Addley, 2001). It turns out that while the scent released on the various underground systems has the same name, "Madeleine," its composition is subtly altered depending on the local conditions (Anon, 2001a,b).

Along similar lines, in 2019, a number of the trams on Vienna's U-bahn trialed perfumed carriages following complaints that the underground vehicles were sometimes unpleasantly smelly during summertime (despite widespread air-conditioning). A pleasant yet subtle citrus fruit scent was introduced in order to minimize malodour (Walker, 2019). As is often the case, this olfactory intervention appears to be as much sensory marketing as anything else. One of the other intriguing reasons for bus services and mass transit to introduce a pleasant scent has been in the hope that it might help nudge more people to use public transport (Poon, 2017). In decades gone by, motorists would sometimes hang a scented card (often in the shape of a pine tree or orange) from the rear-view mirror that would slowly release the matching scent thereby hopefully masking any malodour that might otherwise have been perceptible in the car (for a simple sense-hack involving a clothes peg and essential oil, see Cleary, 2021). Even Tesla have come out with a scented card smelling of musk in the shape of Elon Musk's head. According to the website (https://elonsmusk.co/): "The original Elon Musk air freshener, made with the real scent of Musk. Make your car smell like the world's hardest working billionaire." According to press reports, a number of the airlines also pump fragrance into the air conditioning in their planes in order to help eliminate malodour (McGuire, 2017).

\section{Scent in Motion: Marketing via the Nose}

In recent years, a number of more-or-less successful marketing campaigns have been introduced on various forms of public transport in confined spaces such as the Underground. Olfactory marketing has the advantage over other media that in confined spaces such as the Underground, commuters/travelers are exposed to the message no matter where they look or on what they happen to be attending to visually (cf. Nibbe and Orth, 2017). One such olfactory marketing campaign that was introduced into the London Underground two decades ago was pulled after only a day though. The campaign for the Amaretto di Saronno liqueur brand involved releasing the drink's distinctive almond aroma into the underground. The plan had been to release an almond scent into the ventilation system for 2 weeks, hoping to appeal to the olfactory sensibilities of those who found themselves on the tube. Unfortunately, however, the campaign coincided with the release of an article in the country's most widely read newspaper, informing their readers how to recognize signs of terrorist activity. Commuters, especially those on the underground, were warned to be extremely cautious should they detect an almond-like smell, given that the poisonous gas cyanide is made from almonds (albeit bitter almonds), just like the drink (Jury, 2002; Lim, 2014, p. 84)!

In 2010, on Highway 150 in Moorseville, North Carolina, USA, a huge billboard for Bloom, a division of Food Lion, a grocery store displayed a piece of steak on a fork (see Figure 2). The ScentAir company created a scent that smells of black pepper and BBQ that was pumped out to passing motorists by means of a large fan positioned at its base that blew over a number of BBQ fragrance oil cartridges. The scent was dispersed in the mornings and afternoons when commuter traffic was likely to be at its peak. One bemused motorist described it thus: "It smells like, uh, barbecue, like hickory or something being barbecued and smells like steak." (Aronoff, 2010).

A decade later, scent dispensers were installed on a number of city buses in Seoul, South Korea, that recognized when the Dunkin' Donuts jingle played on the radio. They responded by releasing coffee aroma for the passengers to inhale. The idea behind this Dunkin' Donuts "Flavor Radio" campaign was that after stepping off the bus, the passengers would soon enough come across one of the chain's many stores and thus be primed to pay a visit. With a $16 \%$ spike in visitors to Dunkin' Donuts branches situated close to a bus stop, not to mention a $29 \%$ increase in coffee sales, the evidence suggests that this multisensory marketing strategy (i.e., involving both scent and sound) really did work (Garber, 2012). Others have reported that releasing the smell of coffee on the petrol station forecourt also leads to a dramatic increase in sales (Pape, 2009; Spence, 2015).

In 2013, I was involved in an olfactory marketing campaign with a London-based marketing agency. The campaign involved a specially-modified London taxi (a black cab) being sent out around the capital's streets pumping-out the smell of McCain's Ready Baked Jackets, basically microwavable ovenbaked potatoes (Anon, 2013). At the same time, a few 3D video signs were erected at a number of bus stops. The idea was that curious commuters who chose to push the button on the baked potato were surprised when a pleasant baked potato aroma was released (see Figure 3). In the words of one commentator: "Each billboard includes a fiberglass potato sculpture and a mysterious button: Push it, and the tuber discharges the aroma of "slow oven-baked jacket potatoes."

The following year (i.e., 2014), Tennent Caledonian launched a new drink Lemon T., a light lager mixed with lemon soda. In this case, parts of the Glasgow subway were ambientlyscented with a product-congruent sweet lemon aroma that was supposedly subtle enough not to distract commuters from their journey (Sutton, 2018). Meanwhile, in India, in 2016, the car manufacturer Ford teamed up with advertising agency Kinetic Worldwide to place a number of multisensory billboards to advertise the Ford Mustang at airports (McEleny, 2016). Not only did the motion-activated billboards play the sound of the car's engine to passers-by, but they also emitted smoke to mimic the look and smell of burning tire rubber. Another intriguing example of out-of-home scent marketing comes from Marriott International, who spray scents that are designed to match the destinations offered in its travel program in the vicinity of advertisements displayed in public places (e.g., releasing a coconut aroma for Greece; Mobile Marketing, 2020; Murphy, 2020).

Objections have though, on occasion, been raised to the use of food scents in olfactory marketing. This was exactly what happened when the "Got milk" campaign in California decided 


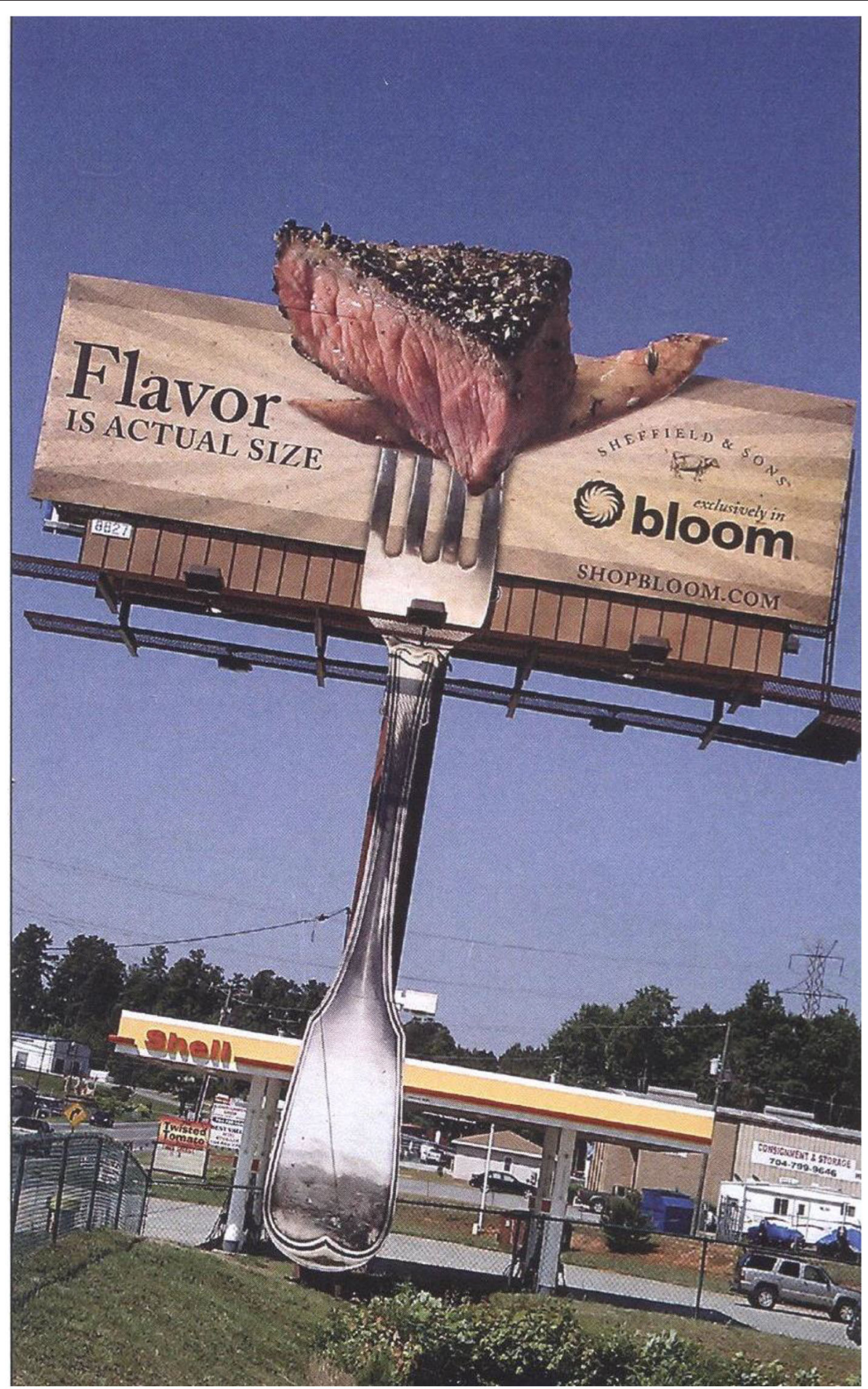

FIGURE 2 | Scented advertisement on Highway 150, North Carolina, USA. In this case, while the commuter is moving, the scent is stationary.

that it would be a good idea to start scenting bus shelters with the aroma of cookies in order to give their advertising something of a multisensory boost. The campaign was pulled within days of its launch over concerns that it was grossly-insensitive to the many hungry homeless people in the state who used the shelters to sleep (Cuneo, 2006; Gordon, 2006; Elliott, 2008; Metcalfe, 2012).

What distinguishes the various olfactory marketing campaigns that have been discussed in this section (as well 


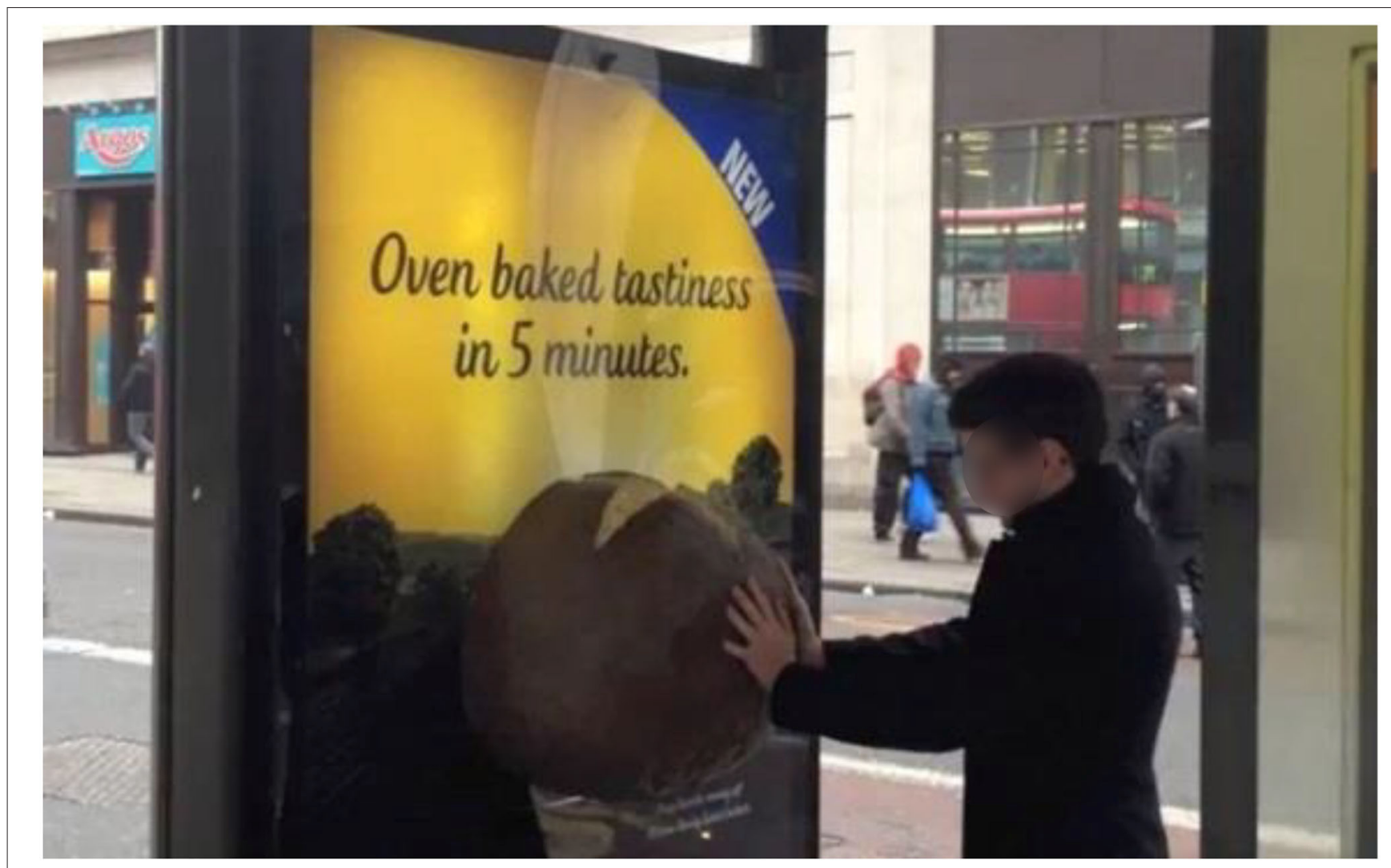

FIGURE 3 | Touch the tattie and smell that delicious oven-baked potato smell. Multisensory marketing at a London bus-stop.

as a couple of other campaigns that took place in British train stations and at Heathrow airport; see Cable, 2014; Polden, 2015) is the typically short-lasting nature of the intervention. These interventions can, though, be seen as part of a wider trend toward the emergence of scent marketing (Morrin, 2010; Sendra-Nadal and Carbonell-Barrachina, 2017; Minsky et al., 2018). As Sutton (2018, p. 132) describes the situation: "In an industry which has been traditionally dominated by visual stimuli, organizations using Out Of Home (OOH) advertising are increasingly utilizing olfactory elements to entice, engage and entertain target audiences." Part of the appeal of scenting public transportation is undoubtedly the captive nature of the audience.

\section{Signature Scents (Branding)}

Given the extensive and growing use of bespoke scent to help deliver a pleasant olfactory identity for everything from sporting venues (Albrecht, 2013; Doll, 2013; Martinez, 2013) to ultrahigh-end apartments (Schroeder, 2018) ${ }^{14}$, and from hotel chains (such as the distinctive White Tea scent from the Westin Hotel Group; Kaysen, 2016; Wiedmann et al., 2016; Minsky et al.,

\footnotetext{
${ }^{14}$ It should though, be noted that some commentators believe that the scenting of different spaces in new building developments is nothing more than a gimmick (Kaysen, 2016).
}

2018; Spence, 2018b) ${ }^{15}$ through to retail stores (Spence et al., 2014). In such cases, the fragrance may be blown in through the ductwork, or else delivered by means of stand-alone machines (Kaysen, 2016; Minsky et al., 2018). One challenge, though, is that scent delivered in one room may well end up being distributed through the ductwork to other parts of the building unintentionally contaminating the entire building's ventilation system (see Lai, 2015). One solution, as proposed by Dmitrenko et al. (2017a), is therefore to build a separate air extraction system (i.e., disconnected from the building's central ventilation system) for an indoor space in which a scent is released.

In terms of the signature scent of transportation companies, it has been the airlines who would appear to have led the way. So, for example, Singapore airlines has long used a particular fragrance Stefan Floridian Waters in its planes (Lindstrom, 2005; Strutner, 2015; see also Carey, 2015). Indeed, commentators often comment on how a sense of luxury in the airline sector is perceived in terms of distinctive, bespoke, scent, for instance Singapore Airlines perfume being experienced not just in the cabin but also in the hot towels that passengers are given to refresh themselves (Wiedmann et al., 2016). Looking to the future, premium land-based transportation services might be able to distinguish themselves, and the experience they provide,

\footnotetext{
${ }^{15}$ Perhaps triggered by claims that people will refuse to check in if they detect a strange smell in the lobby of a hotel (Pacelle, 1992).
} 
in part by the use of luxurious signature scent (see https://www. premiumscenting.com/). Hinting at the possibilities in this space, only last year, Ford patented an app to check ride-share cars for bad smells before a passenger gets in (Maddireddy, 2020; Yeung et al., 2020).

Accepting that branded signature scents might be a good idea for the travel industry more generally, the good news is that there are methods available (such as the semantic differential technique, SDT; Dalton et al., 2008) to help align the qualities of the scent with the key brand attributes (cf. Vogt, 2008; Minsky et al., 2018) ${ }^{16}$. It will be an interesting question for future research to determine whether the design of signature scents based on the synaesthetic associations experienced by creative perfumiers, such as Dawn Goldworm, the successful synaesthetic scent director of 12.29, a New York based fragrance design agency (see Kaysen, 2016; Schroeder, 2018) are any more successful than those based on SDT and/or the crossmodal correspondences (see Spence, 2020e, for a review).

\section{Functional Benefits of Scent in Motion}

An extensive body of research shows that ambient scents can affect people's mood, their perception, and also their behavior (Spence, 2020c,d). Perhaps unsurprisingly, therefore, there has been interest in capitalizing on the functional uses of ambient scent in the context of transportation. This has most frequently been discussed/studied in the context of driving where, unlike for most other forms of transport, the person traveling may well also be the one who is in charge of the vehicle. It is worth noting that any attempt to modulate the driver's state of mind (be it counteract sleepiness, or calm the overexcited driver down) via the functional use of scent is inevitably also going to be experienced by any passengers who are traveling (Spence, 2021a $)^{17}$. Ambient in-car fragrance can help to mask malodour and hence potentially (functionally) improve the driver's mood (Ho and Spence, 2008, 2013), and possibly resulting in their driving more safely too (Baron and Kalsher, 1998). Another functional use of scent in the context of driving is to help alert the sleepy motorist (Martin and Cooper, 2007; Raudenbush et al., 2009; Yoshida et al., 2011; Fruhata et al., 2013). At the same time, however, it should be stressed that the higher visual perceptual load of the driver means that their awareness of ambient scent while on the road is likely to be markedly reduced due to what has been termed "inattentional amnesia" (Forster and Spence, 2018).

A number of further functional uses for scent in the context of driving have been articulated recently by the work of Dmitrenko et al. So, for example, in one study, Dmitrenko et al. (2019) examined the use of olfactory notifications to reduce speeding. Meanwhile, the results of a second study highlighted the possibility of using different olfactory cues to notify the driver of different relevant events (Dmitrenko et al., 2017b; see also Hiroike et al., 2009; Okazaki et al., 2018). Finally, these researchers have also reported how olfactory notifications can

\footnotetext{
${ }^{16}$ Though here it should also be noted that cultural (not to mention individual) differences in the meaning/association of scents have been reported (Trivedi, 2006; see also Truong, 2018).

${ }^{17}$ Of course, this concern also applies to the use of auditory alerts too (see Ho and Spence, 2008).
}

also be used help to reduce the number of driving-relevant mistakes in the simulator setting (Dmitrenko et al., 2018). Note here also that in 2013 Ford cars applied for a patent concerning a smell notification system for drivers (see Kolich and Ford Global Technologies LLC, 2013). Another intriguing functional use for scent in the context of manual or autonomous driving relates to the alleviation of travel/motion sickness (e.g., Keshavarz et al., 2015; Ranasinghe et al., 2020; Schartmüller and Riener, 2020).

Of course, no one needs a high tech gadget in order to deliver the synthetic scent of nature. As was mentioned a little earlier, drivers have been dangling scent-infused cardboard pine trees from their rear-view mirrors for decades. However, the problem with this solution is that our brains tend to adapt pretty quickly to pleasant or neutral smells. So while you might notice the scent as you open your car door, my guess is that you probably won't think about it much after that. Several studies have demonstrated how the periodic delivery of pulsed scent (e.g., peppermint) can help enhance operator performance (e.g., Warm et al., 1991; Ho and Spence, 2005, 2008; Mahachandra et al., 2015). The Aroma Shooter (http://www.aromajoin.com/) which provides a directional olfactory stream might be especially appropriate for those applications where the scent is targeted specifically at the driver (see also Dmitrenko et al., 2016). However, that said, this particular device is no longer positioned in the vehicular context. There is mention in the US Press of another olfactory delivery device Cyrano being possibly used to deliver scents to drivers (see Baig, 2016).

A few years ago, the British company Jaguar looked into developing a scent display for their vehicles. The idea was for the GPS to periodically check on the car's location and instruct the device to pump the appropriate synthetic natural scent into the cabin. For example, just imagine how much more pleasant it would be to drive through the forest if your nostrils were stimulated by the scent of pine, say, or perhaps the wonderful smell of the earth just after it has rained (geosmin does a pretty good job in this regard). At the same time, however, research from the world of entertainment has highlighted how, unless the scent is chosen very carefully, that ambient pine scent is more likely to remind whoever smells it of a cleaning product, rather than bringing them closer to nature (Spence, 2020d, 2021b), even when the source object (e.g., a pine tree) is clearly visible.

In 2004, Citroen launched their C4 model with a nine-scent olfactory display operating through the ventilation system. The scents were split into groups of three, designed to be congruent with notions of "travel," "vitality," and "well-being" and were intended to provide scent for 6 months before it would need to be refilled (Hanlon, 2004). A decade later, Mercedes incorporated an olfactory display in certain of its new models too (Clark, 2013). While such olfactory interventions undoubtedly represent an intriguing direction when it comes to realizing the idea of "scent in motion," my oft-stated belief is that, as with any other olfactorily-enabled digital device, it will ultimately fail for the simple reason that the customer will not think it worthwhile to buy the refill (Spence et al., 2017).

Of course, cost is likely not to be an issue for the owner of a Bentley car that also offers Sterling silver atomizers to personalize the multisensory experience in their Mulliner 
edition cars (see https://www.bentleymotors.com/content/ brandmaster/master/bentleymotors/en/world-of-bentley/ mulliner/personal-commissioning/personalising-your-bentley. html\#3f3f8d7bb768277e2e9b127c73364c6f). Meanwhile, BMW have also been working on creating their own in-car perfumes too for their 7-Series (Boeriu, 2015). According to the latter online commentary: "The optional Ambient Air package features options to ionize the air or fragrance the vehicle interior with selected scents, both of which can be controlled from the air conditioning control console or the iDrive menu. There are three levels of intensity and 8 scents to choose from. The scents can be chosen from the Blue Suite and Green suite, and Golden Suite and Authentic Suite."

While it is easy enough to demonstrate the benefits to the user's mood or experience of adding an extra sensory input (Spence, 2021a), the existence of the "fundamental misattribution error" means that as visually-dominant creatures (Hutmacher, 2019), we typically attribute our enhanced pleasure (or experience) to the visual element of a multisensory experience rather than to the olfactory component. The latter, as was mentioned before, may anyway be missed due to the phenomenon of inattentional anosmia (Forster and Spence, 2018). Who knows whether scent displays might 1 day be used to arouse dozy driver instead of the loud and unpleasant auditory alerts that are more commonly used today. Certainly, it is easy to imagine how pumping out an arousing ambient scent such as cinnamon, peppermint, rosemary, eucalyptus, grapefruit (Fruhata et al., 2013) or lemon might prove to be a much less aversive way of achieving the same result than a loud sound, say (Ho and Spence, 2008, 2013). That said, a multisensory approach to modifying the driver's state is likely going to work best here as elsewhere (Bounds, 1996; Ho and Spence, 2008; Spence, 2012; Fruhata et al., 2013).

The functional use of scent has therefore been considered in relation to modifying various aspects of driver performance and experience (Ho and Spence, 2013; Dmitrenko et al., 2016; Mustafa et al., 2016). However, given the rapid adaptation to constant ambient scent, the periodic release of scent holds much more promise as far as the delivery of functional scents is concerned, especially if you want drivers to pay attention to what they are smelling. It would also be good to have more research showing whether sudden-onset olfactory stimuli can automatically (i.e., exogenously) capture attention in a way that constant ambient odors fail to do, often because they are no longer perceived consciously (Funato et al., 2009; Forster and Spence, 2018; though see also Bordegoni et al., 2017; Spence, 2020c).

Another functional use of scent in the context of transportation relates to research showing that those scents we associate with cleanliness can be used to encourage people not to litter/pick up waste (De Lange et al., 2012). So, for example, the presence of an ambient "clean" scent, such as pine or citrus, can help to make a space appear cleaner. The presence of such scents may also help to reduce littering too. At the same time, however, it should be noted that olfactory priming effects have not always proven so easy to replicate (see Smeets and Dijksterhuis, 2014, for a review). There is also a separate line of empirical research, and hence potential opportunity, to use scent functionally to enhance the passengers' multisensory experience/nudge to engage in more prosocial behaviors (e.g., Schiffman and Siebert, 1991; Gueguen, 2001; Spence, 2002, 2021b; Holland et al., 2005; Liljenquist et al., 2010; De Lange et al., 2012; Henshaw et al., 2018), while at the same time possibly also improving their mood (e.g., Warren and Warrenburg, 1993; Spence, 2020c). Finally, it is worth noting how a pleasant scent was introduced onto bus services and mass transit in Singapore the hope that it might help nudge more people to use public transport (cf. Kutzbach, 2010; Poon, 2017). This scent-sory nudging strategy laid bare in the title of a paper in Bloomberg news by Linda Poon (2017): "To entice riders, Singapore buses get a 'signature scent': Will more people ride public transit if it smells nice?”

\section{New Car Smell: A Multifunctional Olfactory Signal}

One smell that is often mentioned in the context of transportation and which has been noticeably absent from this review so far is "new car smell" (see Aikman, 1951; Moran, 2000a,b,c). While ratings of which models or marques have the best scent are published annually, suggesting they are distinctive, they have never become differentiated enough to support brand recognition in the absence of other cues ${ }^{18}$. The reason for this is because this evocative smell can be considered as relating to several of the categories outlined above, while not really belonging in any one. Modern car interiors tend to smell terrible unless they are suitably treated (Spence, 2002) ${ }^{19}$. The volatile odors (VOCs) released from the plastic/synthetic materials so often used in car interiors in decades gone by used to make them smell unpleasantly fishy (Shea, 1971; Grabbs et al., 2000; Ritter, 2002). At the same time, however, according to research from California, that oh-so-desirable car smell may actually be carcinogenic (Reddam and Volz, 2021; Watson, 2021).

While many of the car companies have teams of expert noses dedicated to the optimization of the synthetic smell that greets the customer (see Moran, 2000b), these scents do not really qualify as signature scents for a couple of reasons: On the one hand, the consumer considers it the smell of the vehicle (i.e., product-intrinsic; Van Lente and Herman, 2001), rather than of the brand. On the other, while different marques do smell somewhat different (i.e., some new cars do smell better than others), the relevant question is whether drivers are able to distinguish between the smell of a new Volkswagen (VW) vs. Ford car, say. In the absence of evidence, my guess is that this distinction is simply too subtle for most drivers to be able to recognize the marque reliably solely on the basis of the new car smell. In fact, it is an intriguing question is to just how many high street brands actually have a distinctive, and instantly recognizable, signature scent beyond the likes of Lush, Subway,

\footnotetext{
${ }^{18}$ Luxury yachts represent a vibrant niche market (one might consider, new yacht smell for the superrich?; https://yachtscent.com/), and holiday cruises are very big business, representing the fastest growing sector of the travel market, at least they were pre-Covid-19 (Giese, 2020). However, I am not aware of any research on the role of scent in this particular environment (though see Hood, 2019, for the recent introduction of a signature fragrance, Ship No. 1, linked to Virgin Voyages cruises). ${ }^{19}$ Some decades ago now, Rolls-Royce even ran a scented add in Architectural Digest that allowed readers to smell the leathery Rolls interior (Gibbs, 1988).
} 
Cinnabon, and perhaps a few others (see Nassauer, 2014). One can only wonder how distinctive the signature scent, Nuance, introduced by General Motors for its Cadillac car in 2003 may have been (Lindstrom, 2005).

SC Gordon Ltd., the coachbuilders of Rolls-Royce cars, have developed their own unique new car smell designed specifically to mimic the aromatic blend of leather and wood of a vintage 1965 Silver Cloud model! The car cologne is applied when new cars come in for repair, and according to Hugh Hadland, Managing Director of the company, "People say they don't understand what we've done, but that their cars come back different and better." It seems that just one dash of the luxury perfume is enough to restore that sense of luxury in even the most expensive of consumer purchases (Seat sniffers, 2000), and can even be used to add value when people come to resell their own car (Aikman, 1951; Hamilton, 1966; Wright, 1966). Intriguingly, surveys consistently highlight a strong relationship between how much consumers like a vehicle's interior smell and how they rate the vehicle's interior overall (Power and Associates, 2000). One other intriguing question here concerns the role of new car scent in the seemingly irrational desire to buy new car--given how rapidly they are known to depreciate (Rohrer, 2008). Intriguingly, new car smell is not appreciated by everyone. Truong (2018) has reported that: "According to JD Power, more than 10\% of drivers in China-the world's largest auto market-complained about the new-car smell in its 2018 survey." Such findings have resulted in Ford filing a patent for a technique to strip its new models of their new car smell in the region.

\section{Food Scents in Transportation}

Before moving on, it is perhaps worth noting in passing that food and drink are often consumed while travelers are on the move. For instance according to an interview with Michael Pollen, North Americans consume $20 \%$ of their meals while at the wheel in their cars (https://news.stanford.edu/news/multi/ features/food/eating.html). This is what is sometimes referred to as dashboard dining or cup-holder cuisine (Hill, 2005; see also Morrison, 2021, for one view of the future of dining in autonomous cars). Designed food experience for passengers on other forms of transport has also occupied the minds of many researchers' (e.g., Horwitz and Singley, 2004; Muecke, 2004; Spence, 2017a,b; Taylor et al., 2019, 2020). Returning to a theme that was mentioned earlier in this review, it has been suggested by de Syon (2008) that the provision of food on airplanes may also be one means of helping passengers to manage their anxiety (though more could certainly be done in this regard; e.g., Delahaye, 2017).

Much of the profit, at least amongst the budget airlines comes from the sale of food and drink, and the on-board duty free shop (Ciesluk, 2020). As such, this must raise the temptation to use smell to sell. Similarly, think only of how the food and beverage offering is used as one of the key differentiators between different classes of service in the air (Economy, Business, First; O'Flaherty, 2015; Spence, 2017a,b). British trains, with their distinction between Standard and First Class carriages, also use the food offering to discriminate between the different classes of service. The challenge in certain transportation situations is to deal with the deleterious effects of the dry air/lowered cabin air pressure, not to mention the $80 \mathrm{~dB}$ of background noise, as has been documented in the case of delivering tasty food in the air (Spence, 2017a,b,c; Spence, 2018a).

As such, one probably needs to consider how the smell associated with any $\mathrm{F} \& \mathrm{~B}$ offering may influence the olfactory atmosphere, not only for those who are eating, but also for those who are not. Indeed, consuming certain forms of food are banned on public transport in some transport systems. For example, it is forbidden to drink alcohol or eat hot foods on many forms of public transport in the UK and elsewhere (see Hello Magazine, 2017). The latter prohibition presumably designed to minimize the olfactory discomfort to the other passengers), while chewing gum has long been banned on public transit in Singapore (presumably to help reduce litter and mess; Metz, 2015). One example of what goes wrong if one doesn't take account of what the aroma of food may remind the passenger of is highlighted by the case of Virgin Australia. The smell of parmesan sandwiches were misinterpreted as the smell of sweaty old socks (both share the volatile compound valeric acid), and made many of the passengers fall sick (Buaya, 2016) ${ }^{20}$.

\section{Future Travel: Space Tourism}

There is growing excitement about the impending emergence of space tourism (Henderson and Tsui, 2019). As several different companies (SpaceX, Virgin Galactic, Space Blue Origin, etc.) compete to be the first to offer a commercial service, important questions remain about the nature of the multisensory experience that the customers will be offered (Obrist et al., 2019). The starting point is not good, given that reports from astronauts describing space as smelling like: "gunpowder, hot metal, welding" (New York Hall of Science, 2016). The repeated recycling of limited air can potentially lead to the build-up of volatile pollutants (Taylor et al., 2019, 2020). At the same time, however, the lowered gravitational pull also leads to the build up of blood in the head, and this may constrict the nasal airways (NPR, 2012), leading to what is known as "space anosmia" (Varma et al., 2000). However, a more pressing problem might be to deal with space sickness that many feel on entering space (Crampton, 1993). As such, any scent that can help to reduce anxiety and/or counteract the effect of travel sickness might be considered a good idea (though see Paillard et al., 2014; Keshavarz et al., 2015).

\section{SCENTED TRAVEL: SCENTED TERMINALS AND STATIONS}

Commercial travel often involves passengers transiting through terminals both prior to, and more briefly upon, arrival. Think of train stations, airports, subway/metro stations, and even bus/tram stops. Such spaces constitute an integral part of the experience of travel. In fact, looking back the discussion of

\footnotetext{
${ }^{20}$ Here one is reminded of Mark Twain's (Clemens, 1957) “The Invalid's Story" in which a man becomes increasingly distressed while riding in a freight car with what he imagines can only be a coffin containing a pungent, putrid corpse. Unable to tolerate the nauseating smell any longer, he eventually jumps off the train into a winter storm, contracting a fatal illness. However, before he dies, he learns that the coffin in the freight car was actually a large crate of cheese.
} 
scenting the metro/underground involved the smell of the terminal not the transportation itself (i.e., the carriages). By contrast, when discussing the scent of air travel, the focus was very much on the scent of the airplanes/airlines rather than the airports (see Klara, 2012). That said, there has been interest in scenting the airline passenger's experience prior to take-off. For instance, two decades ago, British Airways (BA) introduced a functional scent into their airport lounges (Spence, 2002). According to a report that appeared in The Wall Street Journal (Ellison and White, 2000), a signature scent called "Meadow Grass" was introduced into their executive airport lounges. The idea was that the weary business traveler would be greeted by a familiar scent as soon as they walked into the lounge (no matter what continent they happened to be on), signaling that their journey was near its end (or presumably, just beginning). It is noticeable how contemporary scenting strategies tend to try and ensure a consistent olfactory identity across all touch points (i.e., including both airline lounges and the airplane itself). For instance, Delta Airlines deliberately used a fragrance of orange peel, sandalwood, cedar and leather, part of a move to create a signature airline aroma to charm passengers in airport lounge lobbies, such as at Chicago's O’Hare airport (Carey, 2015).

The olfactory ambience of airports would seem to differ substantially as a function of the country that one happens to be transiting through. While most airports are olfactorily neutral ${ }^{21}$, the atmosphere in North American airports tends to be heavy with the smell of food franchises (see Nassauer, 2014). The broadly appealing smell of coffee has become a distinctive smell of train stations and many other public spaces. And while there has been some discussion of given entire shopping centers a branded scent (see Spence et al., 2014), I haven't heard anything similar for airports as yet. That said, pre-Covid-19, I was always struck flying in to Heathrow by the cheap clean fragrance, my response then much like that of those quoted earlier regarding the scenting of the underground that was disbursed throughout the terminal--from what source I never was able to ascertain. In this case, it is unclear into which category we should put the scenting strategy.

Intriguingly, there are also examples of olfactory performance artists who have worked with the scent of such familiar, yet often transitorily experienced, spaces. Consider here only the work of Helgard Haug, a young performance artist who won a prize in support of a public art piece at the subway station Berlin Alexanderplatz, once the social center of East Berlin. In 2000, Haug commissioned a distillation of the scents of Berlin Alexanderplatz that were presented in tiny souvenir glass vials dispensed in the station. The perfumer designed the scent based on his own perception of the station without chemical analysis. $\mathrm{U}$-deur included the smell of bread as one of the primary odors (because there was once a bakery stand in the subway) along with the smells of cleaning agents, oil, and electricity. According to Drobnick (2006), the public response to the project was apparently extraordinary. People wrote that the little sniff-bottle brought to mind memories and associations with the smells of a

\footnotetext{
${ }^{21}$ And of course, the duty free fragrance counters are a distinctive feature of the majority of airports, though the scent is typically not widely dispersed.
}

divided Berlin, for instance, the "dead" stations that West Berlin subway trains went through after passing the Wall. At the same time, thoughts about the Stasi archive with its items saturated with the body odor of East German criminals and dissidents were also triggered in the minds of some.

\section{CHALLENGES WITH CONTROLLING THE OLFACTORY ENVIRONMENT}

The technical means of introducing and controlling scent, and, more importantly, getting the level right, is by no easy, especially in the case of scent in motion. What is more, olfactory adaptation/habituation means that those working in a scented environment may soon lose any awareness of the scent whereas occasional passengers may find the scent to be much stronger (Spence, 2020c). Furthermore, too often (or so it would seem), cheap synthetic scents (or at least scents that are perceived as such) are used. Creating a bespoke solutions can be expensive (Spence et al., 2017), and trade marking specific scents is a challenging business (Hammersley, 1998) thus making innovation in this space even more challenging.

Most successful approaches to scenting the environment, be it in the context of scenting the built environment or scent in motion, as discussed here, do not occur in isolation, but rather involve the coordinated stimulation of multiple senses, be it in the car (e.g., Bijsterveld et al., 2014), in the underground/underground car-park or metro station (Sayin et al., 2015), or while in the air. Here it is important to stress that multisensory interactions often influence olfactory perception (e.g., Velasco et al., 2014). As such, it can be hard to know how exactly a scent will be perceived until it is actually introduced in situ. Indeed, problems associated with sensory overload and sensory incongruency (Malhotra, 1984; Spence, 2020a,b) have been used to explain why the benefits of adding one sense sometimes disappear in real-world interventions when scent and sound interventions have been combined (e.g., Mattila and Wirtz, 2001; Morrin and Chebat, 2005; Fenko and Loock, 2014; see also Spangenberg et al., 2005).

\section{CONCLUSIONS}

While those thinking about the scent of transport in the modern era have often focused on masking the scent of the typically confined space, or of the passengers - both those who are currently present (Walker, 2019) and those who have long since left their olfactory mark (see Robinson, 2016; see also Anon, 2015) - there is also growing interest in branding the experience by means of the introduction of signature scents. To date, this has primarily occurred in the context of the airlines (Lindstrom, 2005; Carey, 2015; Strutner, 2015; Wiedmann et al., 2016), but there seems little reason to believe that the approach will not be extended to other forms of transportation, especially given the dynamic nature of the sector currently (cf. Baskas, 2019). It is crucial, especially at the luxury end of the market, that signature scents are used as part of a multisensory marketing/design strategy (Wiedmann et al., 2016; Spence, 2021a). Typically, the 
most effective sensory interventions engage multiple senses (see Bounds, 1996; Spence, 2012; Fruhata et al., 2013), while ensuring congruency across multiple sensory touchpoints and avoiding the dangers of sensory overload (Spence, 2021a).

At present, the smell is just one of the aspects of the experience of luxury travel that those tempting their customers with the virtual reality (VR) experience before they travel typically fails to capture (Yerman, 2015; though see also Cable, 2014, for the use of scent to help mentally transport travelers to their destination; and Flavián et al., 2021, for the latest research in this area). Perhaps also worth mentioning here are the various that olfactory-displays "on the go" that have been enabled by headmounted displays (HMDs; e.g., Yanagida et al., 2004; Howell et al., 2016; Ranasinghe et al., 2018; Comşa et al., 2019; Saleme et al., 2019; Nakamoto et al., 2020).

A number of scent-based marketing interventions, although typically short-lived, have also been associated with the theme of scent in motion in recent years (although in such cases it is more often the case that the scent itself is static, while the traveler/passenger passes through, or by the scented location). Scent-based marketing interventions, although not yet widespread, continue to flourish (e.g., Garber, 2012; Anon, 2013; Cable, 2014; Polden, 2015; McEleny, 2016; Mobile Marketing, 2020; Murphy, 2020). That said, as we have seen here, problems have, on occasion, arisen in part due to confined space and the involuntary nature of the passenger's engagement with the olfactory stimulus, especially in confined space (cf. Anon, 2001a,b; Jury, 2002; Lim, 2014). Looking to the future, it would seem likely that the development of functional branded scents will increasingly be a feature of our experience of travel (Ho and Spence, 2008, 2013; Spence, 2021a), at the interface between the more artistic and scientific worlds of fragrance (Drobnick, 2006).

The functional use of scent in a passenger transport/travel context includes everything from the suggestion that ambient scents could be used to help reduce anxiety amongst the $40 \%$ of passengers who report that flying makes them anxious (Strutner, 2015) through to attempts to use pleasant scent in order to help tackle motion sickness (Keshavarz et al., 2015; Ranasinghe et al., 2020; Schartmüller and Riener, 2020). Some are even considering whether scent can be used strategically to help nudge more people to take more sustainable and environmentally friendly forms of transport (Poon, 2017). After all, it is worth noting that travel is typically involved when we go on holiday, with the global tourism market estimated to be worth a trillion dollars annually (World Travel Tourism Council, 2017). As such, anything that can be done to help reduce global tourism's carbon footprint, estimated in 2018 (i.e., pre-Covid-19) to represent

\section{REFERENCES}

Addley, E. (2001). Underground Scent Promises Transports of Delight. The Guardian. Available online at: https://www. theguardian.com/uk/2001/apr/24/transport.world (accessed April 24, 2002).

Aikman, L. (1951). Perfume, the business of illusion. Natl. Geograph. 99, 531-550.
$8 \%$ of global greenhouse gas emissions (Lenzen et al., 2018), through sensory nudging (possibly involving olfaction) toward more environmentally-friendly forms of transportation, would seem like an avenue that has to be worth pursuing in the future (cf. Poon, 2017).

One area of particular interest regarding the future of olfactory displays in the automative industry, relates to the emerging benefits of the nature effect (Williams, 2017; Spence, 2021a), the olfactory version of which one might call aromatherapy (Spence, 2003). It will be interesting to see whether the benefits of the nature effect can be incorporated thus delivering a benefit for driver's well-being. It is also interesting here to note how some car companies have been trying to develop vehicle interiors that are so pleasurable that people choose to sit in their car even once their journey has ended. It would seem that getting the olfactory atmosphere right will be a key component to the success of any such enterprise. Another suggestion here relates to the emerging problem about how to facilitate switching between being a passive passenger and an active driver semiautonomous vehicles. Olfactory signaling might help to mark out these different states with driving presumably being associated with a more alerting/arousing state of mind, while the other is presumably more relaxing. Finally here, one might also wonder whether scents could potentially be used to help wayfinding while driving (cf. Hamburger and Knauff, 2019).

Finally, there is a sense in which, at least to your present author, when the proposed form of transport being discussed, moves further into the future, such as for example, Virgin Hyperloop (Giacobbe, 2021), that realizing what taking this new form of transport will smell like somehow makes it more believable, "more real." One might argue that scent, while an important part of the experience of any form of transportation, would be figured out later in the day (given its aesthetic rather than functional role). That scent design (along with sound design) is brought forward in the design process, etc. seems to be playing a role, perhaps a fifth role of olfaction, in making one hypothetical version of the future of transportation, of scent in motion, more believable, somehow more tangible.

\section{AUTHOR CONTRIBUTIONS}

CS wrote and researched all parts of this review.

\section{FUNDING}

This work was supported by a grant from the AHRC Rethinking the Senses Grant AH/L007053/1. 
Anon (2001a). Sniffing out Tube Fragrances. BBC News Online. Available online at: http://news.bbc.co.uk/1/hi/uk/1292690.stm (accessed April 23, 2001).

Anon (2001b). Tube Scent Machine Breaks Down. BBC News Online. Available online at: http://news.bbc.co.uk/2/hi/uk_news/1294795.stm (accessed April 23, 2001).

Anon (2013). McCain Creates the World's First Potato Scented Taxi -Offering Free Hot Jacket Potatoes That Are Cooked on Board in Five Minutes.

Anon (2015). BA Flight Forced to Land Early Because of Smelly Poo. BBC Online. Available online at: https://www.bbc.com/news/newsbeat-31908620 (accessed March 16, 2015).

Anon (2016). How Semi-Autonomous Vehicles Are Helping to Power a Potentially Safer Future on the Road. Wired. Available online at: https://www.wired.com/ brandlab/2016/03/how-semi-autonomous-vehicles-are-helping-to-power-apotentially-safer-future- on-the-road/ (accessed June 21, 2021).

Anon (2021a). Coronavirus: What's the Risk on Transport? BBC News Online. Available online at: https://www.bbc.com/news/health-51736185 (accessed April 22, 2021).

Anon (2021b). Call for Action Over London Luton Airport Emissions and Further Expansion Plans. St. Alban's City.

Aronoff, J. (2010). Grocery Store Erects Steak-Scented Highway Billboard. The Spokesman -Review. https://www.spokesman.com/stories/2010/jun/06/ grocery-store-erects-steak-scented-highway/ (accessed June 6, 2010).

Ba, M., and Kang, J. (2019a). A laboratory study of the sound-odour interaction in urban environments Build. Environ. 147, 314-326. doi: 10.1016/j.buildenv.2018.10.019

$\mathrm{Ba}, \mathrm{M}$., and Kang, J. (2019b). Effect of a fragrant tree on the perception of traffic noise. Build. Environ. 156, 147-155. doi: 10.1016/j.buildenv.2019.04.022

Baig, E. C. (2016). Cyrano Lets You Smell What's on Your iPhone. USA Today. Available online at: https:/www.usatoday.com/story/tech/columnist/baig/ 2016/04/28/cyrano-lets-you-smell-whats-your-iphone/83620924/ (accessed April 8, 2016).

Baron, R. A., and Kalsher, M. J. (1998). Effects of a pleasant ambient fragrance on simulated driving performance: The sweet smell of safety? Environ. Behavi. $30,535-552$.

Baron, R. A., and Ransberger, V. M. (1978). Ambient temperature and the occurrence of collective violence: The "Long, hot summer" revisited. J. Personal. Soc. Psychol. 36, 351-360.

Baskas, H. (2019). My House Smells Like an Airport. Yours Can Too. CNBC. Available online at: https://www.cnbc.com/2019/07/26/my-house-smells-likean-airport-yours-can-too.html (accessed July 28, 2019),

Benfield, J. A., Rainbolt, G. A. N., Troup, L. J., and Bell, P. A. (2020). Anthropogenic noise source and intensity effects on mood and relaxation in simulated park environments. Front. Psychol. 11:570694. doi: 10.3389/fpsyg.2020.570694

Bernard, A. (2014). Lifted: A Cultural History of the Elevator. New York, NY: NYU Press.

Berry, L. L., Carbone, L. P., and Haeckel, S. H. (2002). Managing the total customer experience. Sloan Manage. Rev. 43, 85-89.

Bever, L. (2019). Jewish Family was Booted Off Flight Over 'Body Odor' Says AntiSemitism Is to blame. The Washington Post. Avaialble online at: https://www. washingtonpost.com/transportation/2019/01/25/jewish-family-was-bootedflight-over-body-odor-says-anti-semitism-is-blame/ (accessed January 25, 2019).

Bijsterveld, K., Cleophas, E., Krebs, S., and Mom, G. (2014). Sound and Safe: A History of Listening Behind the Wheel. Oxford: Oxford University Press.

Bloomberg (2017). 'Toxic Fume Events' on Planes Worry Airline Workers. Fortune. Available online at: https://fortune.com/2017/08/09/dangerous-cabin-fumesplanes/ (accessed August 9, 2017).

Boeriu, H. (2015). She Created the Smell of the All-New BMW 7 Series. BMW Blog. Available online at: https://www.bmwblog.com/2015/07/03/she-createdthe-smell-of-the-all-new-bmw-7-series/ (accessed July 3, 2015).

Bordegoni, M., Carulli, M., and Shi, Y. (2017). "Demonstrating the effectiveness of olfactory stimuli on drivers' attention," In International Conference on Research into Design (Singapore: Springer).

Bounds, W. (1996). Sounds and scents to jolt drowsy drivers. Wall Street J. 6, B1-5. Bradley, M. (Ed.). (2015). Smell and the Ancient Senses. London: Routledge.

Buaya, A. (2016). Virgin Flight Passengers VOMIT After They Were Served Parmesan Cheese Sandwiches - Which Made the Entire Aircraft to Smell Like
'Old Socks'. Daily Mail Online. Available online at: http://www.dailymail.co. uk/news/article-4065810/Virgin-Australia-passengers-Perth-Adelaide-sickserved-smelly-parmesan-Cheese.html (accessed December 26, 2016).

Bunyan, R. (2021). Fifty-Two Passengers on One Flight From Delhi to Hong Kong Test Positive for Coronavirus After Landing - Despite ALL Presenting a Negative Test While Boarding. Daily Mail Online. Available online at: https://www. dailymail.co.uk/news/article-9512239/Fifty-two-passengers-one-flight-DelhiHong-Kong-test-positive-Covid-19-landing.html (accessed April 26, 2020).

Burne, J. (2014). Is the Noise of Modern Life Making You ill? It Can Trigger Heart Disease, Blood Pressure and Weight Gain - Even When You Are Asleep. Daily Mail Online. Available online at: http://www.dailymail.co.uk/health/article2653249/Is-noise-modern-life-making-ill-It-trigger-heart-disease-bloodpressure-weight-gain-youre-asleep.html (accessed June 10, 2014).

Byatt, A. S. (2003). "How we lost our sense of smell," in Sightlines, eds M. Bragg and P. D. James (London: Vintage Books).

Cable, S. (2014). What Does Scotland Smell Like? Heathrow 'Scent Globe' Sprays Fragrance That Encapsulates Heather-Capped Highlands and Crisp Loch Air. Daily Mail Online. Available online at: http://www.dailymail.co.uk/ travel/travel_news/article-2866889/Heathrow-Scent-Globe-sprays-fragranceencapsulates-Scotland-s-heather-capped-Highlands-crisp-loch-air.html (accessed December 9, 2014).

Carbone, L. P. (2004). Clued in: How to Keep Customers Coming Back Again and Again. Upper Saddle River, NJ: Prentice Hall.

Carbone, L. P., and Haeckel, S. H. (1994). Engineering customer experiences. Market. Manage. 3, 8-19.

Caress, S. M., and Steinemann, A. C. (2009). Prevalence of fragrance sensitivity in the American population. J. Environ. Health 71, 46-50.

Carey, S. (2015). Airlines Try Signature Fragrances, But Not Everyone Is on Board: Carriers Try Fragrances, But Some Passengers aren't on Board. The Wall Street Journal. Available online at: https://www.wsj.com/articles/airlines-trysignature-fragrances-but-not-everyone-is-on-board-1422832562 (accessed February 1, 2015).

Chapin, F. S. (1974). Human Activity Patterns in the City: Things People Do in Time and Space. New York, NY: Wiley.

Ciesluk, K. (2020). How Do Low Cost Carriers Actually Make Money: A Complete Breakdown. Simple Flying. Available online at: https://simpleflying.com/howlow-cost-carriers-make-money/ (accessed June 14, 2020).

Clark, J. (2013). 2014 Mercedes-Benz S-Class Interior Is "the Essence of Luxury". Available online at: http://www.emercedesbenz.com/autos/mercedesbenz/s-class/2014-mercedes-benz-s-class-interior-is-the-essence- of- luxury/ (accessed March 26, 2013).

Classen, C. (1992). The odor of the other: Olfactory symbolism and cultural categories. Ethos 20, 133-166.

Cleary, B. (2021). How a Simple Clothing Peg Is the Key to Keep Your Car Smelling Fresh All Year Long. Daily Mail Online. Available online at: https://www.dailymail.co.uk/femail/article-9519315/How-simple-clothingpeg-key-car-smelling-fresh-year-long.html (accessed April 28, 2021).

Clemens, S. L. (1957). "The invalid's story," in Complete Short Stories of Mark Twain, ed C. Neider (Garden City, NY: International Collectors' Library).

Colvile, R. (2017). The Great Acceleration: How the World Is Getting Faster, Faster. London: Bloomsbury.

Comşa, I.-S., Saleme, E. B., Covaci, A., Assres, G. M., Trestian, R., Santos, C. A. S., et al. (2019). Do I smell coffee? The tale of a $360^{\circ}$ mulsemedia experience. IEEE MultiMedia 27, 27-36. doi: 10.1109/mmul.2019.2954405

Corbin, A. (1986). The Foul and the Fragrant: Odor and the FRENCH Social Imagination. Cambridge, MA: Harvard University Press.

Crampton, G. H. (1993). Research strategies for motion and space sickness. ORL 55, 175-179. doi: 10.1159/00027 6416

Crawford, W. A., and Holcomb, L. C. (1991). Environmental tobacco smoke (ETS) in airliners-a health hazard evaluation. Aviation Space Environ. Med. $62,580-586$.

Cuneo, A. C. (2006). Milk Board Forced to Remove Outdoor Scent Strip ads. AdAge. Available online at: http://adage.com/article/news/milk-board-forced-removeoutdoor-scent-strip-ads/113643/ (accessed December 6, 2006).

Dalton, P., Maute, C., Oshida, A., Hikichi, S., and Izumi, Y. (2008). The use of semantic differential scaling to define the multi-dimensional representation of odors. J. Sensory Stud. 23, 485-497. doi: 10.1111/j.1745-459X.2008.00167.x 
De Lange, M., Debets, L., Ruitenburg, K., and Holland, R. (2012). Making less of a mess: Scent exposure as a tool for behavioral change. Soc. Influence 7, 90-97. doi: 10.1080/15534510.2012.659509

de Syon, G. (2008). "Is it really better to travel than arrive? Airline food as a reflection of consumer anxiety," in Food for Thought: Essays on Eating and Culture, ed L. C. Rubin (Jefferson, NC: McFarland \& Co.).

Degen, M., and Rose, G. (2012). The sensory experiencing of urban design: the role of walking and perceptual memory. Urban Stud. 49, 3271-3287. doi: $10.1177 / 0042098012440463$

Delahaye, J. (2017). Monarch Airlines May Have Unlocked the Secret to Helping You Relax on a Flight so You Can Avoid 'Air Rage'. The Mirror. Available online at: http://www.mirror.co.uk/lifestyle/travel/monarch-airlinesfood-box-menu-11038358 (accessed August 23, 2017).

Diao, M., Kong, H., and Zhao, J. (2021). Impacts of transportation network companies on urban mobility. Nat. Sustainabil. 4, 494-500. doi: 10.1038/s41893-020-00678-z

Dipodjoyo, G. U. (2019). Personal space in public transportation at Jakarta Indonesia. Int. J. Recent Sci. Res. 10, 34896-34898. doi: 10.24327/ijrsr.2019.1009.3995

Dmitrenko, D., Maggioni, E., Brianza, G., Holthausen, B. E., Walker, B. N., and Obrist, M. (2020). "Caroma therapy: Pleasant scents promote safer driving, better mood, and improved well-being in angry drivers," in Proceedings of the 2020 CHI Conference on Human Factors in Computing Systems (New York, NY).

Dmitrenko, D., Maggioni, E., and Obrist, M. (2017a). "OSpace: Towards a systematic exploration of olfactory interaction spaces," in Proceedings of the 2017 ACM International Conference on Interactive Surfaces and Spaces (New York, NY).

Dmitrenko, D., Maggioni, E., and Obrist, M. (2018). "I smell trouble: using multiple scents to convey driving-relevant information," in Proceedings of the 20th ACM International Conference on Multimodal Interaction (New York, NY).

Dmitrenko, D., Maggioni, E., and Obrist, M. (2019). “Towards a framework for validating the matching between notifications and scents in olfactory in-car interaction," in Extended Abstracts of the 2019 CHI Conference on Human Factors in Computing Systems (New York, NY).

Dmitrenko, D., Maggioni, E., Vi, C. T., and Obrist, M. (2017b). "What did I sniff? Mapping scents onto driving-related messages," in Proceedings of the 9th International Conference on Automotive User Interfaces and Interactive Vehicular Applications (New York, NY).

Dmitrenko, D., Vi, C. T., and Obrist, M. (2016). "A comparison of scentdelivery devices and their meaningful use for in-car olfactory interaction," in Proceedings of the 8th International Conference on Automotive User Interfaces and Interactive Vehicular Applications (Automotive'UI 16) (New York, NY).

Doll, J. (2013). The 'Signature Scent' of Brooklyn's Barclays Center is mysterious. The Atlantic. Available online at: https://www.theatlantic.com/national/archive/ 2013/05/signature-scent-brooklyns-barclays-center-mysterious/315078/ (accessed May 20, 2013)

Dosey, M. A., and Meisels, M. (1969). Personal space and self-protection. J. Personal Soc. Psychol. 11, 93-97.

Drobnick, J. (Ed.). (2006). The Smell Culture Reader. Oxford: Berg.

Edensor, T. (2014). "The social life of the senses: Ordering and disordering the modern sensorium," in A Cultural History of the Senses in the Modern Age, ed D. Howes (London: Bloomsbury Academic).

el-Khoury, R. (2006). "Polish and deodorize: Paving the city in late eighteenthcentury France," in The Smell Culture Reader, ed J. Drobnick (Oxford: Berg).

Elliott, S. (2008). Hot Food, and Air, at Bus Stops. New York, NY: The New York Times.

Ellison, S., and White, E. (2000). 'Sensory' Marketers Say the Way to Reach Shoppers Is the Nose. The Wall Street Journal. Available online at: https://www.wsj.com/ articles/SB975016895886269171 (accessed November 24, 2000).

Evans, G. W., and Wener, R. E. (2007). Crowding and personal space invasion on the train: Please don't make me sit in the middle. J. Environ. Psychol. 27, 90-94. doi: 10.1016/j.jenvp.2006.10.002

Evans, W. N., and Graham, J. D. (1991). Risk reduction or risk compensation? The case of mandatory safety-belt use laws. J. Risk Uncertain. 4, 61-73.

Felipe, N. J., and Sommer, R. (1966). Invasions of personal space. Soc. Probl. $14,206-214$.
Fenko, A., and Loock, C. (2014). The influence of ambient scent and music on patients' anxiety in a waiting room of a plastic surgeon. HERD 7, 38-59.

Flavián, C., Ibáñez-Sánchez, S., and Orús, C. (2021). The influence of scent on virtual reality experiences: The role of aroma-content congruence. J. Business Res. 123, 289-301. doi: 10.1016/j.jbusres.2020.09.036

Fletcher, C. (2005). "Dystoposthesia: emplacing environmental sensitivities," in Empire of the Senses: The Sensual Culture Reader, ed D. Howes (Oxford: Berg).

Forster, S., and Spence, C. (2018). "What smell?" Temporarily loading visual attention induces a prolonged loss of olfactory awareness. Psychol. Sci. 29, 1642-1652. doi: 10.1177/0956797618781325

Friedrich, O. (1984). Trapped in a musical elevator. Time 124 110-112.

Fruhata, T., Miyachi, T., Adachi, T., Iga, S., and Davaa, T. (2013). Doze sleepy driving prevention system (finger massage, high density oxygen spray, grapefruit fragrance) with that involves chewing dried shredded squid. Proc. Comp. Sci. 22, 790-799. doi: 10.1016/j.procs.2013. 09.161

Funato, H., Yoshikawa, M., Kawasumi, M., Yamamoto, S., Yamada, M., and Yanagida, Y. (2009). Stimulation effects provided to drivers by fragrance presentation considering olfactory adaptation. IEEE Intell. Vehic. Sympos. 2009, 881-886.

Garber, M. (2012). The Future of Advertising (Will Be Squirted Into Your Nostrils as You Sit on a Bus). The Atlantic. Available online at: https://www.theatlantic. com/technology/archive/2012/07/the-future-of-advertising-will-be-squirtedinto-your-nostrils-as-you-sit-on-a-bus/260283/ (accessed July 26, 2012).

Giacobbe, A. (2021). Exclusive First Look at Richard Branson's Hyperloop Propulsion Pods. Architectural Digest. Available online at: https://www. architecturaldigest.com/story/exclusive-first-look-richard-bransonshyperloop-propulsion-pods (accessed January 27, 2021).

Gibbs, N. R. (1988). The sweet smell of success? Time 32.

Giese, M. (2020). COVID-19 Impacts on Global Cruise Industry: How Is the Cruise Industry Coping With the COVID-19 Crisis? KPMG Blog. Available online at: https://home.kpmg/xx/en/blogs/home/posts/2020/07/covid-19-impacts-onglobal-cruise-industry.html (accessed July 23, 2020).

Goetz, A. R. (2019). "The airport as an attraction: the airport city and aerotropolis concept," in Air Transport: A Tourism Perspective, eds A. Graham and F. Dobruszkes (Amsterdam: Elsevier).

Gordon, R. (2006). At Bus Stops, Scents of Dissent. The Philadelphia Inquire.

Gould, W. R. (2017). How to Calm Anxiety When You're on a Flight. NBC News. Available online at: https://www.nbcnews.com/better/health/your-4step-guide-overcoming-your-fear-flying-ncna786746 (accessed July 27, 2017)

Gouveia, N. C., and Maisonet, M. (2005). "Health effects of air pollution: An overview," in: Air Quality Guidelines: Global Update 2005. Regional Office for Europe (Denmark: World Health Organization).

Grabbs, J. S., Corsi, R. L., and Torres, V. M. (2000). Volatile organic compounds in new automobiles: Screening assessment. J. Environ. Eng. 126, 974-977. doi: 10.1061/(ASCE)0733-9372(2000)126:10(974)

Gueguen, N. (2001). Effect of perfume on prosocial behavior of pedestrians. Psychol. Rep. 88, 1046-1048. doi: 10.2466/pr0.2001.88.3c.1046

Hamburger, K., and Knauff, M. (2019). Odors can serve as landmarks in human wayfinding. Cogni. Sci. 43:e12798. doi: 10.1111/cogs.12798

Hamilton, A. (1966). What science is learning about smell. Sci. Digest 55, 81-84.

Hammersley, F. M. (1998). The smell of success: Trade dress protection for scent markets. Marquette Intellect. Property Law Rev. 2, 105-156.

Hanlon, M. (2004). Citroen Adds a Sense of Smell to the New C4. Available online at: https://newatlas.com/go/3643/ (accessed June 21, 2021).

Hello Magazine (2017). Eating Could be Banned on the Tube - Find Out Why: A Similar Ban Has Already Been Introduced in New York. Hello Magazine. Available online at: https://www.hellomagazine.com/cuisine/2017072440863/ possible-eating-ban-tube/ (accessed July 24, 2017).

Henderson, I. L., and Tsui, W. H. K. (2019). "The role of niche aviation operations as tourist attractions," in Air Transport - A Tourism Perspective, eds A. Graham and F. Dobruszkes (Amsterdam: Elsevier).

Henshaw, V. (2014). Urban Smellscapes: Understanding and Designing City Smell Environments. New York, NY: Routledge.

Henshaw, V., McLean, K., Medway, D., Perkins, C., and Warnaby, G. (Eds.). (2018). Designing With Smell: Practices, Techniques and Challenges. New York, NY: Routledge. 
Hill, M. (2005). Car Cuisine. CBS News. Available online at: https://www.cbsnews. com/news/car-cuisine/ (accessed November 9, 2005).

Hiroike, S., Doi, S., Wada, T., Kobayashi, E., Karaki, M., Mori, N., et al. (2009). "Study of olfactory effect on individual driver under driving," in ICME International Conference on Complex Medical Engineering (New York, NY).

Ho, C., and Spence, C. (2005). Olfactory facilitation of dual-task performance. Neurosci. Lett. 389, 35-40. doi: 10.1016/j.neulet.2005.07.003

Ho, C., and Spence, C. (2008). The Multisensory Driver: Implications for Ergonomic Car Interface Design. Aldershot: Ashgate Publishing.

Ho, C., and Spence, C. (2013). Affective multisensory driver interface design. Int. J. Vehicle Noise Vibration. 9, 61-74. doi: 10.1504/IJVNV.2013.053817

Holland, R. W., Hendriks, M., and Aarts, H. (2005). Smells like clean spirit. Nonconscious effects of scent on cognition and behavior. Psychol. Sci. 16, 689-693. doi: 10.1111/j.1467-9280.2005.01597.x

Hood, B. (2019). 'It smells Like Ship': Richard Branson's New Virgin Voyages Fragrance ad is the Funniest Thing you'll See Today: Virgin Voyages is Releasing Its Very Own Ship-Inspired Fragrance, Ship No. 1. Robb Report. Available online at: https://robbreport.com/lifestyle/news/virgin-voyages-fragrance-ship-no2887193/ (accessed December 13, 2019).

Horowitz, M. J., Duff, D. F., and Stratton, L. O. (1964). Body-buffer zone: exploration of personal space. Arch. Gene. Psychiatry 11, 651-656.

Horwitz, J., and Singley, P. (Eds.). (2004). Eating Architecture. Cambridge, MA: MIT Press.

Howell, M. J., Herrera, N. S., Moore, A. G., and McMahan, R. P. (2016). A reproducible olfactory display for exploring olfaction in immersive media experiences. Multimedia Tools App. 75, 12311-12330. doi: $10.1007 / \mathrm{s} 11042-015-2971-0$

Hutmacher, F. (2019). Why is there so much more research on vision than on any other sensory modality? Front. Psychol. 10:2246. doi: 10.3389/fpsyg.2019.02246

Jury, L. (2002). Whiff of Almond Falls Victim to Terror Alert. The Independent. Available online at: https://www.independent.co.uk/news/media/whiff- ofalmond-falls-victim-to-terror-alert-133417.html (accessed November 14, 2002)>

Jütte, R. (2005). A History of the Senses: From Antiquity to Cyberspace (trans. James Lynn). Cambridge: Polity Press.

Kaysen, R. (2016). Aroma: The New Building Amenity. The New York Times. Available online at: https://www.nytimes.com/2016/10/23/realestate/aromathe-new-building-amenity.html (accessed June 24, 2021).

Kennedy, D. P., Gläscher, J., Tyszka, J. M., and Adolphs, R. (2009). Personal space regulation by the human amygdala. Nat. Neurosci. 12, 1226-1227. doi: $10.1038 / \mathrm{nn} .2381$

Keshavarz, B., Stelzmann, D., Paillard, A., and Hecht, H. (2015). Visually induced motion sickness can be alleviated by pleasant odors. Experi. Brain Res. 233, 1353-1364. doi: 10.1007/s00221-015-4209-9

Klara, R. (2012). Something in the Air. Available online at: http://www.adweek.com/ brandmarketing/something-air-138683/\#/ (accessed November 28, 2017).

Klepeis, N. E., Nelson, W. C., Ott, W. R., Robinson, J. P., Tsang, A. M., Switzer, P., et al. (2001). The National Human Activity Pattern Survey (NHAPS): A resource for assessing exposure to environmental pollutants. J. Exposure Sci. Environ. Epidemiol. 11, 231-252. doi: 10.1038/sj.jea.7500165

Kolich, M., and Ford Global Technologies, L. L. C. (2013). In-Vehicle Smell Notification System. U.S. Patent 8,448,739.

Kurczewski, N. (2020). Cars That Are Almost Self-Driving. US News.

Kutzbach, M. (2010). Megacities and Megatraffic. Access Magazine, Fall.

Lacour, M., Zunder, T., Schmidtke, K., Vaith, P., and Scheidt, C. (2005). Multiple chemical sensitivity syndrome (MCS) - Suggestions for an extension of the U.S. MCS-case definition. Int. J. Hygiene Environ. Health 208, 141-151. doi: 10.1016/j.ijheh.2005.01.017

Lai, M. K. (2015). "Universal scent blackbox: Engaging visitors' communication through creating olfactory experience at art museum," in Proceedings of the $33^{\text {rd }}$ Annual International Conference on the Design of Communication (Limerick: ACM).

Lanza, J. (2004). Elevator Music: A Surreal History of Muzak, Easy-Listening, and Other Moodsong. Ann Arbor, MI: University of Michigan Press.

Largey, G. P., and Watson, D. R. (1972). The sociology of odors. Am. J. Sociol. 77, 1021-1034.

LaTour, K. A., and Carbone, L. P. (2014). Sticktion: assessing memory for the customer experience. Cornell Hospital. Q. 55,
342-353. Available online at: http://scholarship.sha.cornell.edu/articles/ 496/

Lawless, S. (2020). Common Scents: How Parasite Puts Smell at the Heart of Class War. The Guardian. Available online at: https://www.theguardian.com/film/ 2020/feb/13/parasite-smell-bong-joon-ho (accessed June 24, 2021).

Leimbach, T. (2017). Scent, Sensibility, and the Smell of a City. Available online at: https://theconversation.com/scentssensibility-and-the-smell-of-a-city-71271 (accessed June 2, 2021).

Lenzen, M., Sun, Y.-Y., Faturay, F., Ting, Y.-P., Geschke, A., and Malik, A. (2018). The carbon footprint of global tourism. Nat. Clim. Change 8, 522-8. doi: 10.1038/s41558-018-0141-x

Liberatore, S. (2021). Rideshare Apps Like Uber and Lyft are Making Traffic Jams Worse Because More Commuters Choose to Hail a Car Instead of Taking Public Transport, MIT study reveals. Daily Mail Online. Available online at: https://www.dailymail.co.uk/sciencetech/article-9517127/Rideshare-appslike-Uber-Lyft-making-traffic-jams-worse-MIT-study-reveals.html (accessed June 24, 2021).

Liljenquist, K., Zhong, C., and Galinsky, S. (2010). The smell of virtue: Clean scents promote reciprocity and charity. Psychol. Sci. 21, 381-383. doi: 10.1177/0956797610361426

Lim, C. J. (2014). Food City. New York, NY: Routledge.

Lindstrom, M. (2005). Brand Sense: How to Build Brands Through Touch, Taste, Smell, Sight and Sound. London: Kogan Page.

Love, S. (2018). Sick Building Syndrome: Is it the Buildings or the People Who Need Treatment? The Independent. Available online at: https://www.independent. co.uk/news/long_reads/sick-building-syndrome-treatment-finland-healthmould-nocebo-a8323736.html

Luke, T. C., and Rodrigue, J.-P., and Osterholm, M. (2020). "Transportation and pandemics," in The Geography of Transport Systems, ed J.-P. Rodrigue (New York, NY: Routledge).

Maddireddy, M. (2020). Ford patents app to check ride-share cars for bad smells before you get in: The solution to living with unpleasant odors and even allergens could be a car that measures how bad it is in that ride share you just called. Car and Driver. Available online at: https://www.caranddriver.com/ news/a32010208/ford-smell-detecting-car-patent/

Mahachandra, M., Yassierli, and Garnaby, E. D. (2015). The effectiveness of invehicle peppermint fragrance to maintain car driver's alertness. Proc. Manufact. 4, 471-477. doi: 10.1016/j.promfg.2015.11.064

Malhotra, N. K. (1984). Information and sensory overload. Information and sensory overload in psychology and marketing. Psychol. Market. 1, 9-21.

Manalansan, I. V. M. (2006). "Immigrant lives and the politics of olfaction in the global city," in The Smell Culture Reader, ed J. Drobnick (Oxford: Berg).

Martin, G. N., and Cooper, J. A. (2007). “Adding zest to difficult journeys: Odour effects on simulated driving performance," in: Paper Presented at the BPS Annual Conference.

Martinez, J. (2013). The Barclays Center has its Own Signature Scent. Complex Media. Available online at: https://www.complex.com/sports/2013/05/thebarclays-center-has-its-own-signature-scent (accessed May 20, 2013).

Matthews, S. (2020). Keeping the Middle Seat Empty on Airplanes May HALVE the Risk of Covid-19 Spreading, Statistician Claims. Daily Mail Online. Available online at: https://www.dailymail.co.uk/news/article-8493875/Keeping-middleseat-airplanes-HALVE-risk-Covid-19-spreading.html (accessed July 6, 2020).

Mattila, A. S., and Wirtz, J. (2001). Congruency of scent and music as a driver of in-store evaluations and behavior. J. Retail. 77, 273-289. doi: 10.1016/S0022-4359(01)00042-2

McEleny, C. (2016). Ford Targets Luxury Travelers With "Sensory" Billboards in India. The Drum. Available online at: http://www.thedrum.com/news/2016/08/ 22/ford-targets-luxury-travelers-sensory-billboards-india (accessed January 4 , 2016).

McGeeham, P. (2005). For Train Riders, Middle Seat isn't the Center of Attraction. New York, NY: The New York Times.

McGuire, C. (2017). Heaven Scent! Smelly Flights Could Soon be a Thing of the Past Thanks to Perfume Pumped Into Plane Cabins. Daily Mail Online. Available online at: http://www.dailymail.co.uk/travel/travel_news/article4152042/ Whyairlinespumpingperfumeplanecabins.html (accessed January 24, 2017).

McLean, K. (2018). "Communicating and mediating smellscapes: The design and exposition of olfactory mappings," in Designing With Smell: Practices, 
Techniques and Challenges, eds V. Henshaw, K. McLean, D. Medway, C. Perkins, and G. Warnaby (New York, NY: Routledge).

Metcalfe, J. (2012). Inside Smellvertising, the Scented Advertising Tactic Coming Soon to A City Near You. CityLab. Available online at: http://www.citylab.com/ design/2012/02/inside-smellvertising-scented-advertising-tactic-comingbus-stop-near-you/1181/ (accessed June 24, 2021).

Metz, E. (2015). Why Singapore Banned Chewing Gum. BBC News Online. Available online at: https://www.bbc.com/news/magazine-32090420 (Accessed, June 24, 2021).

Minsky, L., Fahey, C., and Fabrigas, C. (2018). Inside the Invisible but Influential World of Scent Branding. Harvard Business Review. Available online at: https://hbr.org/2018/04/inside-the-invisible-but-influential-worldof-scent-branding (accessed June 24, 2021).

Misra, T. (2015). This 19th Century 'Stench Map' Shows How Smells Reshaped New York City: Malodorous Industries Moved From Manhattan to Brooklyn, Shifting the Industrial Landscape. Bloomberg City Lab. Available online at: https://www.bloomberg.com/news/articles/2015-03-27/this-19th-centurystench-map-shows-how-smells-reshaped-new-york-city (accessed June 24, 2021).

MobileMarketing (2020). Marriott Campaign Uses Scented OOH, Day Part and Weather Triggers to Drive Bookings. Available online at: bit.ly/2GbUXYS (accessed August 26, 2020).

Moran, T. (2000a). Ah, the Aroma of a Just-Baked Sedan. New York, NY: New York Times.

Moran, T. (2000b). Sniffing Car Parts: Yes, the Job Stinks. New York, NY: New York Times.

Moran, T. (2000c). The Mysterious Human Sense of Smell: So Primitive and so Powerful. New York, NY: New York Times.

Morley, N. (2015). Urban Smells and Roman Noses. in Smell and the Ancient Senses, ed M. Bradley (London: Routledge).

Morrin, M. (2010). "Scent marketing an overview," in Sensory Marketing: Research on the Sensuality of Products, ed A. Krishna (New York, NY: Taylor \& Francis Group).

Morrin, M., and Chebat, J. C. (2005). Person-place congruency: The interactive effects of shopper style and atmospherics on consumer expenditures. J. Serv. Res. 8, 181-191. doi: 10.1177/1094670505279420

Morrison, R. (2021). The Future of Car Travel? Incredible Self-Driving Electric Car Concept Can Hoover up the Pollution From Other Vehicles and Includes a Dining Room-Style Space That Can Be Turned Into a Double BED - and Could Go Into Production by 2023. Daily Mail Online. Available online at: https://www.dailymail.co.uk/sciencetech/article-9516117/Electriccar-concept-hoover-pollution-vehicles.html (accessed April 27, 2021).

Muecke, M. (2004). "Food to go: The industrialization of the picnic," in Eating Architecture, eds J. Horwitz and P. Singley (Cambridge, MA: MIT Press).

Murphy, D. (2020). Marriott Campaign Uses Scented OOH, Day Part and Weather Triggers to Drive Bookings. Mobile Marketing. Available online at: https://mobilemarketingmagazine.com/marriott-uses-scented-out-of-homeday-part-and-weather-triggers-to-drive-hotel-bookings. Retrieved from bit.ly/2GbUXYS (accessed May 1, 2021).

Murphy, M. (2021). UK Government Award £2.5m Fund for Flying Taxi Research and Demonstrations in South West Region. Available online at: https://www. taxi-point.co.uk/post/uk-government-award-2-5m-fund-for-flying-taxiresearch-and-demonstrations-in-south-west-region (accessed January 26, 2021).

Mustafa, M., Rustama, N., and Siran, R. (2016). The impact of vehicle fragrance on driving performance: what do we know? Proc. Soc. Behav. Sci. 222, 807-815. doi: 10.1016/j.sbspro.2016.05.173

Nakamoto, T., Hirasawa, T., and Hanyu, Y. (2020). "Virtual environment with smell using wearable olfactory display and computational fluid dynamics simulation," In IEEE Conference on Virtual Reality and 3D User Interfaces (VR) (New York, NY).

Nassauer, S. (2014). Using Scent as a Marketing Tool, Stores Hope itand Shoppers-Will Linger: How Cinnabon, Lush Cosmetics, Panera Bread Regulate Smells in Stores to Get You to Spend More. The Wall Street Journal. Available online at: http://www.wsj.com/articles/ SB10001424052702303468704579573953132979382 (accessed June 24, 2021).
New York Hall of Science (2016). What Does Space Smell Like? Available online at: https://www.youtube.com/watch?v=dEpKCSuGEjE (accessed June 21, 2021).

Nibbe, N., and Orth, U. R. (2017). "Odor in marketing," in Springer Handbook of Odor, ed A. Buettner (Cham: Springer).

Novaco, R., Stokols, D., and Milanesi, L. (1990). Objective and subjective dimensions of travel impedance as determinants of commuting stress. Am. J. Commun. Psychol. 18, 231-257.

NPR (2012). Space Travel Can Affect Astronauts' Sense of Taste and Smell. Physics Today. Available online at: https://physicstoday.scitation.org/do/10.1063/PT.5. 025900/full/ (accessed February 24, 2012).

Nyirinkindi, E., and Paris, A. (2020). Preventing Mega-Cities From Becoming Mega Gridlocks. World Bank Blogs. Available online at: https://blogs.worldbank.org/ ppps/preventing-mega-cities-becoming-mega-gridlocks (accessed June 24, 2021).

Obrist, M., Tu, Y., Yao, L., and Velasco, C. (2019). Space food experiences: designing passenger's eating experiences for future space travel scenarios. Front. Comp. Sci. 1:3. https://doi.org/10.3389/fcomp.2019.00003.

O'Flaherty, M. C. (2015). Flying at the Height of Luxury. The Times.

Okazaki, S., Haramaki, T., and Nishino, H. (2018). "A safe driving support method using olfactory stimuli," in Conference on Complex, Intelligent, and Software Intensive Systems (Cham: Springer).

Orwell, G. (1937). The Road to Wigan Pier. London: Victor Gollancz.?

Ott, W. R., and Roberts, J. W. (1998). Everyday exposure to toxic pollutants. Sci. Am. 278, 72-77.

Owen, D. (2019). Is Noise Pollution the Next Big Public-Health Crisis? The New Yorker. Available online at: https://www.newyorker.com/magazine/2019/ 05/13/is-noise-pollution-the-next-big-public-health-crisis (accessed June 24, 2021).

Pacelle, M. (1992). Many People Refuse to Check in if a Hotel Has Odors in the Lobby. Wall Street Journal.

Paillard, A. C., Lamôr,é, M., Etard, O., Millot, J. L., Jacquot, L., Denise, P., et al. (2014). Is there a relationship between odors and motion sickness? Neurosci. Lett. 566, 326-330. doi: 10.1016/j.neulet.2014.02.049

Pallini, T. (2020). It's Been 20 Years Since Smoking was Completely Banned on All US Flights. Here's How Smoking on Planes Went From Normal to Banned. Business Insider. Available online at: https://www.businessinsider.com/whendid-smoking-get-banned-on-planes-in-the-us-2020-2 (accessed March 8, 2020).

Pape, P. (2009). It Makes Scents: Olfactory Marketing Brings Pleasant Aromas to Customers Pumping Fuel. NACS Magazine. Available online at: http://www. scentandrea.com/MakesScents.pdf (accessed June 24, 2021).

Pasztor, A., and Tangel, A. (2020). U.S. Air Force Gives Lift to Flying Taxis: Military Endorsement Could Bring Novel Electric Vehicles Closer to Reality. The Wall Street Journal. Available online at: https://www.wsj.com/articles/u-s-air-forcegives-lift-to-flying-taxis- 11607596206 (accessed June 24, 2021).

Paton, G. (2019). Toxic Tube Lines are World's Worst for Air Pollution. The Times.

Peltzman, S. (1975). The effects of automobile safety regulation. J. Polit. Economy $83,677-725$.

Pirsig, R. M. (1974). Zen and the Art of Motorcycle Maintenance. London: Bodley Head.

Polden, J. (2015). From Sun Cream to Freshly Cut Grass! Vending Machine Stocked With Bottles of Scented Air Brings the Smell of Summer to Busy Train Station. Daily Mail Online. Available online at: http://www.dailymail.co.uk/travel/ travel_news/article-3187183/From-sun-cream-freshly-cut-grass-Vendingmachine-stocked-bottles-scented-air-brings-smell-summer-busy-trainstation.html (accessed August 8, 2015).

Poon, L. (2015). Wake Up and Smell Your City: Why Smell Expert Sissel Tolaas is on a Mission to Capture and Replicate the "Smellscapes" of Cities Around the World. Bloomburg City Lab. Available online at: https://www.bloomberg.com/news/articles/2015-11-04/artist- sissel-tolaason-how-to-capture-the-smells-of-your-city (accessed June 24, 2021).

Poon, L. (2017). To Entice Riders, Singapore Buses get a 'Signature Scent': Will More People Ride Public Transit if it Smells Nice? Bloomberg City Lab. Available online at: https://www.bloomberg.com/news/articles/2017-03-08/singaporebuses-now-have-a-special-smell-to-entice-riders (accessed June 24, 2021). 
Popovich, N., Migliozzi, B., Patanjali, K., Singhvi, A., and Huang, J. (2019). See How the World's Most Polluted Air Compares With Your City's. New York, NY: The New York Times. Available online at: https://www.nytimes.com/ interactive/2019/12/02/climate/air-pollution-compare-ar-ul.html (accessed June 24, 2021).

Potter, D. S. (1999). "Odor and power in the Roman empire," in Constructions of the Classical Body, ed J. Porter (Ann Arbour, MI: University of Michigan).

Power, J. D., and Associates (2000). Automotive Performance, Execution and Layout (APEAL) Studies.

Prisco, J. (2019). A Short History of the Elevator. CNN Style. Available online at: https://edition.cnn.com/style/article/short-history-of-the-elevator/ index.html (accessed June 24, 2021).

Radnedge, A. (2019). Toxic Tube Air 'Is a Health Risk to Travellers and Staff. Metro.

Ranasinghe, N., Jain, P., Tolley, D., Tailan, S. K., Yen, C. C., and Do, E. Y.-L. (2020). "Exploring the use of olfactory stimuli towards reducing visually induced motion sickness in virtual reality," in Symposium on Spatial User Interaction. 1-9. doi: 10.1145/3385959.3418451

Ranasinghe, N., Jain, P., Tram, N. T. N., Koh, K. C. R., Tolley, D., Karwita, S., et al. (2018). "Season traveller: multisensory narration for enhancing the virtual reality experience," in Proceedings of the 2018 CHI Conference on Human Factors in Computing Systems, eds R. Mandryk and M. Hancock (New York, NY: ACM).

Raudenbush, B., Grayhem, R., Sears, T., and Wilson, I. (2009). Effects of peppermint and cinnamon odor administration on simulated driving alertness, mood and workload. North Am. J. Psychol. 11, 245-256.

Reddam, A., and Volz, D. C. (2021). Inhalation of two Prop 65-listed chemicals within vehicles may be associated with increased cancer risk. Environ. Int. 149:106402. doi: 10.1016/j.envint.2021.106402

Repace, J. (2004). Flying the smoky skies: Secondhand smoke exposure of flight attendants. Tobacco Control 13(Suppl. 1), i8-i19. doi: 10.1136/tc.2003.003111

Ritter, S. (2002). New car smell: VOCs account for the characteristic 'newness'. Chem. Eng. News 80:45. doi: 10.1021/cen-v080n020.p045

Robinson, M. (2016). San Francisco's Subway has a Creative Solution to Stop Its Elevators From Smelling Like Urine. Business Insider. Available online at: https://www.businessinsider.com/bart-elevators-urine-2016-8 (accessed June 24, 2021).

Rohrer, F. (2008). The New Car Mystery. BBC News. Available online at: http:// news.bbc.co.uk/1/hi/magazine/7764777.stm (accessed June 24, 2021).

Saleme, E. B., Covaci, A., Mesfin, G., Santos, C. A. S., and Ghinea, G. (2019). Mulsemedia DIY: A survey of devices and a tutorial for building your own mulsemedia environment. ACM Comput. Surv. 52, 1-29. doi: 10.1145/3319853

Sayin, E., Krishna, A., Ardelet, C., Decré, G. B., and Goudey, A. (2015). "Sound and safe": The effect of ambient sound on the perceived safety of public spaces. Int. J. Res. Market. 32, 343-353. doi: 10.1016/j.ijresmar.2015.06.002

Schaaff, S. V. (2019). Lots of Americans Have a Fear of Flying. There Are Ways to Overcome the Anxiety Disorder. Available online at: https:// www.washingtonpost.com/health/lots-of-americans-have-a-fear-offlying-there-are-way-to-overcome-the-anxiety-disorder/2019/10/11/ d4746d84-d338-11e9-86ac-0f250cc91758_story.html (accessed October 11, 2019).

Schartmüller, C., and Riener, A. (2020). "Sick of scents: Investigating noninvasive olfactory motion sickness mitigation in automated driving," in 12th International Conference on Automotive User Interfaces and Interactive Vehicular Applications (New York, NY).

Schiffman, S. S., and Siebert, J. M. (1991). New frontiers in fragrance use. Cosmet. Toilet. 106, 39-45.

Schivelbusch, W. (2014). The Railway Journey: The Industrialization of Time and Space in the Nineteenth Century. Oakland, CA: University of California Press.

Schroeder, J. (2018). Inside the \$30m Miami Condo that Comes With Its Own 'Scent Identity': Olfactory Specialist Spends 6 Months With New Buyers to Design Their Personal Scent That is Diffused Through the HVAC System. Daily Mail Online. Available online at: http://www.dailymail.co.uk/news/ article-5936585/29million-condo-Miami-comes-custom-scent-identity.html (accessed June 23, 2021).

Seat sniffers (2000). Beyond Online. Available online at: http:///www.beyond2000. com/news/Jul_00/story_694.html (accessed June 21, 2021).

Sendra-Nadal, E., and Carbonell-Barrachina, Á. A. (Eds.). (2017). Sensory and Aroma Marketing. Wageningen, NL: Wageningen Academic Publishers.
Shea, K. P. (1971). The new-car smell, environment: Science and policy for sustainable development. Int. J. 13, 2-9. doi: 10.1080/00139157.1971.9931125

Smart, V. (2017). Where to, sir? Investor 95, 7-10.

Smeets, M. A. M., and Dijksterhuis, G. B. (2014). Smelly primes - when olfactory primes do or do not work. Front. Psychol. 5:96. doi: 10.3389/fpsyg.2014.00096

Sommer, R. (1959). Studies in personal space. Sociometry 22, 247-260.

Sommer, R. (1969). Personal Space. The Behavioural Basis of Design. Englewood Cliff, NJ: Prentice-Hall.

Spangenberg, E. R., Grohmann, B., and Sprott, D. E. (2005). It's beginning to smell (and sound) a lot like Christmas: The interactive effects of ambient scent and music in a retail setting. J. Business Res. 58, 1583-1589. doi: 10.1016/j.jbusres.2004.09.005

Spence, C. (2002). The ICI Report on the Secret of the Senses. London: The Communication Group.

Spence, C. (2003). A new multisensory approach to health and well-being. In Essence 2, 16-22.

Spence, C. (2012). Drive safely with neuroergonomics. Psychologist 25, 664-667.

Spence, C. (2015). Leading the consumer by the nose: On the commercialization of olfactory-design for the food and beverage sector. Flavour 4:31. doi: 10.1186/s13411-015-0041-1

Spence, C. (2017a). Gastrophysics: The New Science of Eating. London: Viking Penguin.

Spence, C. (2017b). Tasting in the air: A review. Int. J. Gastronomy Food Sci. 9, 10-15. doi: 10.1016/j.ijgfs.2017.05.001

Spence, C. (2017c). Drinking in the Skies. Class Magazine, Winter, 66-68.

Spence, C. (2018a). Drinking on the Move: Recommendations for Drinking in the Air, on Land, and Sea. The Cocktail Lovers.

Spence, C. (2018b). "Retail, scent \& service design," in Designing With Smell: Practices, Techniques and Challenges, eds V. Henshaw, K. McLean, D. Medway, C. Perkins, and G. Warnaby (New York, NY: Routledge).

Spence, C. (2020a). Designing for the Multisensory Mind. Architectural Design: Neuroarchitecture: Designing with the Mind in Mind 42-49.

Spence, C. (2020b). Senses of space: Designing for the multisensory mind. Cognit. Res. 5:46. doi: 10.1186/s41235-020-00243-4

Spence, C. (2020c). Using ambient scent to enhance well-being in the multisensory built environment. Front. Psychol. 11:598859. doi: 10.3389/fpsyg.2020. 598859

Spence, C. (2020d). Scenting the anosmic cube: On the use of ambient scent in the context of the art gallery or museum. i-Perception 11, 1-26. doi: $10.1177 / 2041669520966628$

Spence, C. (2020e). Olfactory-colour crossmodal correspondences in art, science, \& design. Cognit. Res. 5:52. doi: 10.1186/s41235-020-00246-1

Spence, C. (2021a). Sensehacking: How to Use the Power of Your Senses for Happier, Heathier Living. London: Viking Penguin.

Spence, C. (2021b). Scent in the context of live performance. i-Perception 11, 1-28. doi: $10.1177 / 2041669520985537$

Spence, C., Puccinelli, N., Grewal, D., and Roggeveen, A. L. (2014). Store atmospherics: a multisensory perspective. Psychol. Market. 31, 472-488. doi: 10.1002/mar.20709

Spence, C., Ranasinghe, N., Velasco, C., and Obrist, M. (2017). Digitizing the chemical senses: Possibilities \& pitfalls. Int. J. Hum. Comp. Stud. 107, 62-74. doi: 10.1016/j.ijhcs.2017.06.003

Steinemann, A. (2019). International prevalence of fragrance sensitivity. Air Q. Atmosph. Health 12, 891-897. doi: 10.1007/s11869-019-00699-4

Strutner, S. (2015). Airlines Infuse Planes With Smells to Calm You Down (and Make You Love Them). Huffington Post. Available online at: https://www.huffpost.com/entry/airlines-infuse-planes-with-smells-to-calmyou-down-and-make-you-love-themn551028d0e4b01b796c526510?guccounter =1\&guceHreferrer=aHR0cHM6Ly93d3cuZ29vZ2xlLmNvbS8\&gucereferrersig =AQAAAMien9yOuzBcvhJVmOdYsHWBpOwfVWbWQGEI1RHQlxjJp7F3 U0MpJiFIPTCw9emfepO1jE3KumR8H18ZVjGcvKUZiZwIDTWYghxN3xAZ K69u4QriwMYs3-Zj04bhQFMxKvoDIzCOLiMqQkqC8ZdzfE4i8vLVB912Mi jxTdjAqS (accessed March 25, 2015).

Sutton, P. (2018). "The use of scent in out of home (OOH) advertising," in Designing With Smell: Practices, Techniques and Challenges, eds V. Henshaw, K. McLean, D. Medway, C. Perkins, and G. Warnaby (New York, NY: Routledge).

Tafalla, M. (2013). A world without the olfactory dimension. Anatom. Rec. 296, 1287-1296. doi: 10.1002/ar.22734 
Tafalla, M. (2014). Smell and anosmia in the aesthetic appreciation of gardens. Contempor. Aesthe. 12:2014. Available online at: http://hdl.handle.net/2027/ spo.7523862.0012.019

Tan, Q. H. (2013). Smell in the city: smoking and olfactory politics. Urban Stud. 50, 55-71. doi: 10.1177/0042098012453855

Taylor, A., Beauchamp, J., Briand, L., Demaria Pesce, V., Heer, M., Hummel, T., et al. (2019). A taste for space. Int. J. Food Sci. Technol. 35, 36-41. doi: 10.1002/fsat.3304_10.x

Taylor, A. J., Beauchamp, J., Briand, L., Heer, M., Hummel, T., Margot, C., et al. (2020). Factors affecting flavor perception in space: does the spacecraft environment influence food intake by astronauts? Crit. Rev. Food Sci. Technol. 19, 3439-3475. doi: 10.1111/1541-4337.12633

The Local (2019). Switzerland's SBB Sets Sights on Hi-Tech Flying Taxi Service. The Local. Available online at: https://www.thelocal.ch/20190114/switzerlandssbb-sets-sights-on-hi-tech-flying-electric-taxi-service/ (acceesed January 14, 2019).

Thompson, N. (2014). How to Protect Your Personal Space on the Tube. The Daily Telegraph. Available online at: https://www.telegraph.co.uk/travel/ destinations/europe/united-kingdom/england/london/articles/How-toprotect-your-personal-space-on-the-Tube/ (accessed July 25, 2014).

Trivedi, B. (2006). Recruiting smell for the hard sell. New Sci. 2582, 36-39.

Truong, A. (2018). Ford's Found a Way to Appease Chinese Consumers Who Hate the New-Car Smell. Quartz. Avaialble online at: https://qz.com/1469827/fordsfound-a-way-to-appease-chinese-consumers-who-hate-the-new-car-smell/ (accessed November 20, 2018).

Ury, H. K., Perkins, N. M., and Goldsmith, J. R. (1972). Motor vehicle accidents and vehicular pollution in Los Angeles. Arch. Environ. Health 25, 314-322.

Valenti, L. (2018). Off-White and Byredo Just Launched a Perfume Called Elevator Music-And it's Already a Cult Obsession. Vogue. Avaialble online at: https://www.vogue.com/article/off-white-byredo-fragrance-elevator-musicclothing-collaboration-virgil-abloh-ben-gorham

Van Lente, R., and Herman, S. J. (2001). "The smell of success - exploiting the leather aroma," in Human Factors in Automative Design (SP-1591). SAE Technical Paper Series, 2001-01-0047 (Detroit, MI).

van Veldhoven, K., Kiss, A., Keski-Rahkonen, P., Robinot, N., Scalbert, A., Cullinan, P., et al. (2019). Impact of short-term traffic-related air pollution on the metabolome - results from two metabolome-wide experimental studies. Environ. Int. 123, 124-131. doi: 10.1016/j.envint.2018. 11.034

Varma, M., Sato, T., Zhang, L. H., and Meguid, M. M. (2000). Space flight related anorexia. Lancet 356, 681-681. doi: 10.1016/s0140-6736(05) 73828-9

Velasco, C., Balboa, D., Marmolejo-Ramos, F., and Spence, C. (2014). Crossmodal effect of music and odor pleasantness on olfactory quality perception. Front. Psychol. 5:1352. doi: 10.3389/fpsyg.2014.01352

Velux YouGov Report, (2018). The Indoor Generation: Effects of Modern Indoor Living on Health, Wellbeing and Productivity. Available online at: www.velux.nn/indoorgeneration (accessed June 21, 2021).

Vogt, H. (2008). Creating the Signature Scent. Brand Strategy Insider. Available online at: https://www.brandingstrategyinsider.com/creating-thesi/\#.YImET5BKg2w (accessed June 21, 2021).

Walker, S. (2019). Passengers Incensed: Vienna Adds Perfumed Trains to E1 a Day Travel. The Guardian. Available online at: https://www.theguardian. com/world/2019/jul/19/vienna-trials-perfumed-subway-trains-passengersincensed-austria-u-bahn (accessed June 23, 2021).

Wargocki, P. (2001). Measurements of the effects of air quality on sensory perception. Chem. Senses 26, 345-348. doi: 10.1093/chemse/26.3.345

Warm, J. S., Dember, W. N., and Parasuraman, R. (1991). Effects of olfactory stimulation on performance and stress in a visual sustained attention task. J. Soc. Cosmetic Chem. 42, 199-210.
Warren, C., and Warrenburg, S. (1993). Mood benefits of fragrance. Perfumer Flavorist 18, 9-16.

Watson, C. (2021). 'New Car Smell' Is the Scent of Carcinogens, and Even Short Trips May Overexpose us. Science Alert. Available online at: https://www. sciencealert.com/a-20-minute-commute-puts-you-at-risk-of-unacceptablyhigh-levels- of-carcinogens (accessed June 23, 2021).

Wattanacharoensil, W. (2019). "The airport experience," in Air Transport - A Tourism Perspective, eds A. Graham and F. Dobruszkes (Elsevier), 177-189.

Wells, L. (1988). Beauty: Making new scents. New York, NY: The New York Times Magazine.

WHO Technical Report (2013). Review of Evidence on Health Aspects of Air Pollution - REVIHAAP Project.

Wickenden, D. (2021). The Agitators: Three Friends Who Fought for Abolition and Women's Rights. New York, NY: Simon \& Schuster.

Wiedmann, K.-P., Labenz, F., Haase, J., and Hennigs, N. (2016). Soothe Your Senses: A Multisensory Approach to Customer Experience Management and Value Creation in Luxury Tourism. European Business Review. Available online at: http://www.europeanbusinessreview.com/soothe-your-senses/

Wilde, G. J. S. (1982). The theory of risk homeostasis: Implications for safety and health. Risk Anal. 2, 209-225.

Williams, F. (2017). The Nature Fix: Why Nature Makes us Happier, Healthier, and More Creative. London: W. W. Norton \& Company.

Wintersberger, P., Dmitrenko, D., Schartmüller, C., Frison, A.-K., Maggioni, E., Obrist, M., et al. (2019). "S (C) ENTINEL: monitoring automated vehicles with olfactory reliability displays," in Proceedings of the 24th International Conference on Intelligent User Interfaces.

Woodward, M., Dixon, S., Hamilton, J., and Goodall, W. (2017). Deloitte - Driving Connectivity. Global Automotive Consumer Study: Future of Automotive Technologies. Available online at: https://www2.deloitte.com/content/dam/ Deloitte/uk/Documents/manufacturing/deloitte-uk-driving-connectivity.pdf (accessed June 21, 2021).

World Travel and Tourism Council (2017). Travel \& Tourism: Economic Impact 2017. Available online at: https://www.wttc.org/-/media/files/reports/ economic-impact-research/regions-2017/world2017.pdf (accessed June 21, 2021).

Wright, R. H. (1966). Why is an odour? Nature 209, 551-554

Yanagida, Y., Kawato, S., Noma, H., Tomono, A., and Tesutani, N. (2004). Projection based olfactory display with nose tracking. IEEE Virt. Real. 2004, 43-50.

Yerman, J. (2015). Upper-Class Immersion: Virgin Atlantic's Virtual Reality Sales Pitch. Available online at: https://apex.aero/2015/11/19/virgin-atlantic-virtualreality (accessed June 21, 2021).

Yeung, J. B., MacNeille, P. R., Malke, D., Van Hoecke, P. L. J., Gusikhin, O. Y., and Liu, Y. (2020). Transportation System Using Odor Preferences. US Patent: US20200111189 A1.

Yoshida, M., Kato, C., Kakamu, Y., Kawasumi, M., Yamasaki, H., Yamamoto, S., et al. (2011). "Study on stimulation effects for driver based on fragrance presentation," Proceeding of MVA2011 IAPR Conference on Machine Vision Applications

(Nara).

Conflict of Interest: The author declares that the research was conducted in the absence of any commercial or financial relationships that could be construed as a potential conflict of interest.

Copyright (C) 2021 Spence. This is an open-access article distributed under the terms of the Creative Commons Attribution License (CC BY). The use, distribution or reproduction in other forums is permitted, provided the original author(s) and the copyright owner(s) are credited and that the original publication in this journal is cited, in accordance with accepted academic practice. No use, distribution or reproduction is permitted which does not comply with these terms. 